\title{
Concentrate or diversify? The relationship between tenant concentration and REIT performance
}

\author{
Chen Zheng ${ }^{1}$ (D) Bing Zhu
}

Accepted: 16 February 2021 / Published online: 18 March 2021

(c) The Author(s) 2021

\begin{abstract}
This paper examines how a concentrated tenant base affects the operating performance and market valuations of US REITs. We observe that REITs adopting a concentrated tenant base present higher corporate cash flows and lower expenses. However, we identify a concentration discount effect that REITs with a more concentrated tenant base experience lower market valuations. We argue that this concentration discount is a result of the tradeoffs between the impacts of the tenant base on the operating performance, risk levels and growth potentials. We find that a concentrated tenant base is associated with higher liquidity risk and lower dividend growth, resulting in an inflated discount factor. Our findings are not subject to sub-samples of focused or diversified REITs and stay robust after correcting for the selection bias as well as controlling for the lease structure, tenant quality and anchor tenant effect.r
\end{abstract}

Keywords Tenant concentration $\cdot$ REIT performance $\cdot$ REIT valuations $\cdot$ Herfindahl index

JEL Classification L $25 \cdot \mathrm{G} 30 \cdot \mathrm{G} 32$

\section{Introduction}

Concentrate or diversify? This is an extensively researched question in the business literature where the benefits are weighed against the costs associated with a diversified or concentrated strategy in order to determine the net impact on a firm's financial performance or market valuations. While the first thing we learn about risk management is not to put all the eggs in one basket, this branch of literature suggests that diversification does not necessary improve the firm value due to the associated costs. Following the

Chen Zheng

chen.zheng@henley.ac.uk

Bing Zhu

b.zhu@tum.de

1 Department of Real Estate and Planning, Henley Business School, University of Reading, Reading RG6 6AH, UK

2 Department of Civil, Geo and Environmental Engineering, Technical University of Munich, Arcisstraße 21, 80333 Munich, Germany 
seminal paper by Montgomery (1994) who finds that firms with a concentrated business strategy perform better than their diversified counterparts, the emerging literature generally supports a diversification discount, or concentration premium, effect. The negative impact of diversification on the firm performance and asset valuations has been widely recorded across different industries (Berger and Ofek 1995; Campbell et al. 2003; Comment and Jarrell 1995; Hund et al. 2010).

Due to the complex nature of the definition of diversification at the corporate level, most of the empirical studies examine the diversification of the underlying business lines, i.e. SIC-defined sectors or assets. Capozza and Seguin (1999) propose REITs as an ideal testing lab to create accurate measures of diversification due to the simplicity and transparency of the underlying asset holdings of REITs. Most studies following Capozza and Seguin (1999) find a discount effect of both property type and property location diversification on REIT valuations (Cronqvist et al. 2001; Campbell et al. 2003; García and Norli 2012; Kang and Kim 2008; Landier et al. 2009).

As REITs hold a substantial amount of "hard assets" and their growth heavily rely on rental income producing properties (Lu et al. 2015), the underlying tenant base is as important a factor as the asset type and geography to a REIT's success. However, the research on tenants is surprisingly scarce despite the fact that a REIT, as a corporate, often places tenants at the center of its business. This paper represents a first attempt to extend the corporate concentration concept to the tenant level and empirically test the impact of tenant concentration on REITs operating performance and market valuations.

We follow Capozza and Seguin (1999) and exploit the conceptual framework of the REIT business by testing the impact of tenant concentration on a REIT's cash flows, expenses and determinants of its market valuation. While a limited number of studies focus on how tenants affect the corporate behaviors of REITs, such as the financing choice and liquid management (Liu and Liu 2013; Lu-Andrews 2017; Liu et al. 2019), our study provides the first set of empirical tests on a direct relationship between tenants' characteristics and REIT performance as well as valuations. The contributions of this study are threefold.

Firstly, we find that REITs adopting a concentration strategy for the underlying tenant base present better operating performance. Specifically, REITs with more concentrated tenants present higher property-level cash flows and lower expenses, including management costs and financial expenses, leading to considerably higher corporate-level cash flows. This supports the argument that suppliers with concentrated customers can improve their operating efficiency by establishing a long-term stable relationship with their customers (Patatoukas 2012; Irvine et al. 2016).

Secondly, we identify a discount effect of tenant concentration (hereafter concentration discount effect) on REITs market value despite its positive effect on the operating performance. We find that REITs with a more concentrated tenant base experience lower valuations measured by price-to-FFO ratio, market-to-book ratio and Tobin's Q, which is in contrast to the diversification discount effect that has been widely documented in the finance and real estate literature. This concentration discount effect holds after we control for the property type and geographic concentration. More interestingly, we find that REITs with a more concentrated tenant base are associated with lower liquidity and lower dividend growth, indicating a higher required return, hence a higher discount rate, which ultimately explains the concentration discount in valuations.

Thirdly, this study adds to the REIT diversification literature by introducing a third dimension other than asset type and property location diversification; it represents a first attempt to propose a precise measure of tenant concentration at the REIT level by 
constructing the Herfindahl index based on the shares of tenants' contributions to the overall rental revenues.

The rest of the paper is structured as follows: Sect. 2 briefly reviews the relevant literature and develops the hypotheses; Sect. 3 summarizes the sample selection, variable construction and methodology; Sect. 4 discusses the empirical results, followed by a series of robustness tests in Sect. 5; the final section concludes.

\section{Literature Review and Hypothesis Development}

\subsection{Concentration and Corporate Value}

Montgomery (1994) presents the first attempt to summarize the relevant empirical evidence of the relation between corporate focus and value, concluding that diversification does not necessarily improve firm performance. On the contrary, he finds that concentrated firms tend to perform better than diversified ones, a phenomenon that is referred to as the "diversification discount" in the literature. Early studies exclusively focus on the diversification of business lines across different industries and generally support a negative relationship between the firm-level diversification and firm value (Lang and Stulz 1994; Berger and Ofek 1995; Comment and Jarrell 1995; Chen and Chen 2011; Bielstein et al. 2018).

One dominant explanation for this discount effect is the latent costs associated with the agency and transparency problems of diversified firms (Scharfstein and Stein 2000; Lamont and Polk 2002; Dittmar and Shivdasani 2003; Ahn and Denis 2004; Cheng and Wu 2018). Shin and Stulz (1998) and Rajan et al. (2000) find that the internal capital market could fail as the level of diversification across business lines increases. The managers of the standalone divisions in a diversified firm have better opportunities to focus on self-interests and engage in rent-seeking, leading to inefficient resource allocations. Krishnaswami and Subramaniamb (1999) argue that it is the increased information asymmetry associated with a diversified structure that causes the discount effect. However, the empirical evidence on the relationship between the information asymmetry and the diversification discount is rather mixed (Hadlock et al. 2001; Thomas 2002; Best et al. 2004).

Recent research development on the relationship between customer concentration and supplier performance suggests two competing theories: 1) suppliers' performance is punished due to the increasing bargaining power of major concentrated customers as well as the increased cash flow risk associated with a concentrated customer base (Lee et al. 2020); 2) suppliers can also benefit from a concentrated customer base by establishing a stable customer-supplier relationship and achieving operating efficiency (Kwak and Kim 2020). Although tenants are like customers to REITs because they are the cash flow generators, they also differ in that it is less likely for the tenants to find substituting suppliers supplying properties or spaces with similar qualities due to the nature of real estate business. Therefore, the bargaining power perspective is naturally weakened, leaving REITs as an ideal laboratory to test the second theory.

REITs provide an ideal testing ground to construct more precise measures of diversification across different dimensions. Given the simplicity of REITs holdings and the transparency in the corporate operation, REITs make it possible to examine the impact of diversification within a single industry on project- and corporate-level performance separately. REITs also allow us to explore whether diversification incurs more management costs given that the General and Administrative costs (G\&A) of a REIT company is mainly 
attributed to its management (Capozza and Seguin 1999). Capozza and Seguin (1999) find that the property-level cash flows of diversified REITs are actually higher, undermining the agency cost argument that managers in diversified firms are more likely to pursue less profitable projects. However, they find that this increased property-level cash flow does not benefit shareholders as the increased management costs associated with diversification offset it, leaving the corporate-level cash flows unaffected. Consistent with the diversification discount effect, they find that REITs with more concentrated portfolios experience higher valuations.

The following studies largely support this diversification discount in REITs (Cronqvist et al. 2001; Campbell et al. 2003; Kang and Kim 2008; Ro and Ziobrowski 2012). Cronqvist et al. (2001) find that REITs focusing on one or two asset types experience a premium in the market value compared to REITs with more diversified asset types. Campbell et al. (2003) find that a more geographically concentrated portfolio leads to a higher increase in shareholders' wealth in property acquisitions. García and Norli (2012) extend the geographic concentration to general industrial companies and find that a higher level of geographic concentration is associated with higher excessive stock returns. Hartzell et al. (2014) and Ling et al. (2018b) also confirm a negative relationship between the REIT value and geographic diversification.

\subsection{Tenant Quality and REIT Performance}

The literature on the underlying tenants of REITs is limited due to the data availability as REITs are not required to disclose detailed information on tenants. Recent studies tend to focus on the quality of the tenants. By using a sample of retail REITs only, Liu and Liu (2013) find that REITs experience negative abnormal returns following the bankruptcy of their tenants. Lu-Andrews (2017) adopts direct measures of the tenant quality-tenants' credit ratings and Altman Z-scores - and finds that the incentives to hold liquid assets are reduced for REITs with more quality tenants as better financial health of the tenants indicate higher stability in a REIT's cash flows. Liu et al. (2019) argue that higher tenant quality reflects better asset quality, leading to a higher liquidation value. Ambrose et al. (2018) represent the first attempt to study the concentration of the tenant base. They find that mortgages on retail properties with a more diversified tenant base present higher spreads than mortgages on single-tenant properties.

\subsection{Hypothesis Development}

The gross revenue at the property level is essentially a product of the net lettable area, the rental rate and the occupancy rate, each of which could be affected differently by tenant concentration. Given that more circulation space is needed when a building is occupied by more tenants, a more concentrated tenant base can increase the efficiency of the space. Tenants who require a block of space are less likely to relocate due to higher relocation expenses. Moreover, when REITs rely on a concentrated tenant strategy they care more about the tenant quality and long-term stability, indicating a lower turnover and higher occupancy rate (Lu-Andrews 2017). This increased stability comes with a potential price that these tenants are more likely to have greater negotiation power over the rental rate, as suggested by the literature on customer concentration (Kwak and Kim 2020), which could reduce the aforementioned benefits. However, the greater heterogeneity in properties caused by the unique location and the characteristics of the buildings 
means that it is much harder for major concentrated tenants to find substitutes for their desired property spaces. While the location might have a more direct effect on certain types of properties such as retail, the agglomerative effects associated with a property, widely documented by the agglomerative literature (Rosenthal and Strange 2020), indicate that other properties, such as offices, are also hard to be substituted. Overall, it suggests that, unlike customers who can easily find substitute suppliers, the concentrated tenants have only limited bargaining power. The discussion above suggests an overall enhanced cash flow generating ability of a concentrated tenant base. Therefore, we form our first hypothesis as follows:

Hypothesis 1: Tenant concentration has a positive effect on property-level cash flows.

The overall expenses of a REIT company are generally attributable to its propertylevel operating costs, corporate-level management costs and financial expenses. While a more concentrated tenant base is easier for the property-level operation, it is also likely that the major tenants require better service, leading to higher operating costs. However, due to the increased simplicity of the lease terms, it is natural to think that a more concentrated tenant base requires lower management costs at the corporate level. We argue that a concentrated tenant strategy would also reduce the financial expenses as the increased transparency makes it easier for banks' valuation practices. Therefore, we form our second hypothesis as follows:

Hypothesis 2: REITs with a more concentrated tenant base are associated with lower management and financial costs.

While a concentrated strategy might only have a weak impact on property-level cash flows, the reduction in corporate expenses indicates an overall positive impact of tenant concentration on corporate cash flows, hence our third hypothesis:

Hypothesis 3 REITs with a more concentrated tenant base present higher corporate-level cash flows.

US REITs are required to hold at least $75 \%$ real estate assets, implying that the value of a REIT company is largely dependent on the value of its underlying assets. Therefore, the fundamental determinants of a REIT's value are the net operating income (NOI) from properties and the discount factor. In other words, the effect of the tenant concentration on REIT value is a trade-off of its impacts on the cash flows, risk levels and growth respectively. REITs relying on a concentrated tenant base for their income potentially present higher risk. Due to the nature of the business, the growth potential of a REIT company is related to its rent escalation. Given that the leases are usually mid- to long-term in the commercial real estate sector, the more it relies on a concentrated tenant base, the less room there is for a REIT company to review and re-negotiate the rent in the mid-term, indicating lower growth potentials. This increased risk and decreased growth potential result in an inflated discount factor of REITs with a more concentrated tenant base. This increased discount factor ultimately leads to a discount in the valuation. Therefore, we form our fourth hypothesis as follows: 
Hypothesis 4 REITs with a more concentrated tenant base experience lower valuations due to the increased liquidity risk and reduced growth potential.

\section{Data and Methodology}

We collect data for 204 listed US Equity REITs between 2003 and 2015. The data on company characteristics including the tenant information is collected from S\&P Global Market Intelligence Database (formerly known as SNL Financials). Market Intelligence Database records the thirty largest tenants for each public REIT and the percentage of the total revenue attributed to each tenant. It should be noted that Market Intelligence Database does not collect tenant information for Multi-family and Hotel REITs, hence these are not included in our sample. There are 104 Equity REITs with tenant information available with an average of 14 tenants reported for each REIT. While the total number of tenants for some REITs might be more than 30 , the revenue generated by tenants ranked after 30 is trivial. Therefore, we believe that this is unlikely to systematically affect the accuracy of our Herfindahl index measure of tenant concentration and the estimations. Based on these 104 REITs, we further collect data on tenant and firm characteristics to form an unbalanced panel over 13 years.

We use a variety of measures for the operating performance and market valuations of REIT companies. For cash flow performance, we measure the gross rental income (RENT), net operating income $(N O I)$ and funds from operations $(F F O)$. We use both property-level operating costs $(O P C O S T)$ and the firm-level G\&A expenses $(G \& A)$ to measure the management costs. The financial cost is measured by the interest expenses (INTEREST). All of the operating measures are scaled by the total assets. To measure the market valuations, we use the share price to FFO $(P / F F O)$, the market-to-book ratio $(M / B)$, and Tobin's $\mathrm{Q}(Q)$.

To explore the underlying channel through which tenant concentration affects market valuations of REITs, we model the determinants of the discount rate. Firstly, we include the turnover ratio to proxy for the liquidity risk (Acharya and Pedersen 2005; Glascock and Lu-Andrews 2015; Alcock and Steiner 2018), which is computed as the trading volume of a company for a given year divided by the end-of-year outstanding value of the common stocks (TURNOVER). Barinov (2014) shows that the turnover ratio is positively related to the liquidity. Secondly, we use the dividend growth rate (DIVGROWTH) to proxy for REITs' growth. REITs are income pass-through and tax efficient vehicles, i.e., the dividends are exempt from tax. To maintain the tax-exempt status, one of the requirements is for REITs to pay at least $90 \%$ of their income as dividends. As any retained earnings are still subject to tax, REITs usually voluntarily pay more than the required minimum $90 \%$, which means that REITs have little or no retained earnings and rely heavily on external funding. Due to the historic cost approach to record real estate assets under the US GAAP and the distortions caused by depreciations and capital gains/losses, net income does not represent the actual cash flow of a REIT company. Instead, a commonly used measure in the REIT industry is funds from operations (FFO) which adjusts the net income for depreciation and net capital gains. Since FFO represents the actual cash available for distribution for US REITs, we calculate the dividend growth rate as the FFO growth rate, which is the difference between current and previous years, multiplied by the FFO payout ratio.

The classic way to account for market power or concentration is to construct the Herfindahl-Hirschman Index (HHI). We follow this approach and construct the Herfindahl index at the tenant level (HHI_Tenant) to measure tenant concentration. The HHI measures the 
concentration of properties of a REIT company across its tenants. Specifically, it is calculated by squaring the revenue share of each tenant with respect to the total revenues of all tenants for the given REIT $i$ in a given year $t$, and then summing the squared shares across the tenants, as presented in Eq. (1):

$$
H I_{i, y}^{\text {Tenant }}=\sum_{l=1}^{L}\left(H_{i, l, y}\right)^{2},
$$

where $H_{i, l, y}$ is the revenue share of each tenant $l$ for REIT $i$ with $l=1,2, \ldots, L$ in year $y . L$ is the total number of tenants of REIT $i$. HHI_Tenant ranges from 0 to 1 , with 1 representing only one tenant of a REIT company and an absolute concentration. The lower the HHI value, the less focused the underlying tenant base of a REIT company is.

We also need to account for the corporate-level diversification of property types and locations. We follow the same approach to measure geographic and property type concentration by using HHI measures. For geographic concentration (HHI_Geo), it is calculated by squaring the market share of properties located in each MSA with respect to the total size of properties for the given REIT $i$ in a given year $y$, and then summing the squared shares across the MSAs, as presented in Eq. (2):

$$
H H I_{i, y}^{G e o}=\sum_{l=1}^{L}\left(\frac{P_{i, l, y}}{S_{i, y}}\right)^{2},
$$

where $P_{i, l, y}$ is the size (square feet) of properties of REIT $i$ located in MSA $l$ with $l=1$, $2, \ldots, L$ in year y; $S_{i, y}$ is the total size of properties held by REIT $i$ in year $y ; L$ is the total number of MSAs where REIT $i$ invests.

Similarly, property type concentration (HHI_Type) is calculated as Eq. (3):

$$
H H I_{i, y}^{\text {Type }}=\sum_{l=1}^{L}\left(\frac{Q_{i, l, y}}{S_{i, y}}\right)^{2},
$$

where $Q_{i, l, y}$ is the size (square feet) of properties of REIT $i$ that belongs to type $l$ with $l=1$, $2, \ldots, L$ in year $y ; S_{i, y}$ is the total size of properties held by REIT $i$ in year $y . L$ is the total number of asset types that REIT $i$ holds. ${ }^{1}$

It is natural to think that REITs have greater incentives to adopt a concentrated tenant base when they can hold long-term leases or when their tenant quality is good. Therefore, it is important to control for the lease structure and tenant quality at REIT level. To capture the long-term lease, we follow the method used by Lu-Andrews (2017). For a given REIT, the share of long-term lease (LEASE) is calculated as Eq. (4):

$$
\text { LEASE }_{i, t}=\frac{\text { Rent }_{i, t}^{\text {expiring } 6 \text { year }}}{\text { Total Rent }_{i, t}},
$$

\footnotetext{
${ }^{1}$ For HHI_Geo and HHI_Type, we also use the adjusted cost as the shares in the Herfindahl index, following Ling et al. (2018a). The adjusted cost is the maximum of (1) the reported book value, (2) the initial cost of the property, or (3) the historic cost of the property including capital expenditures and tax depreciation.
} 
where Rent $t_{i, t}^{\text {expiring } 6 \text { yeart }}$ is the share of base rents to be received from operating leases expiring during the sixth and thereafter fiscal years following the current fiscal year; and Total Rent ${ }_{i, t}$ is the total value of the base rents for REIT $i$ in year $t$.

According to Liu et al. (2019), real assets with longer lease maturity are of better quality which means the measure of the long-term lease also to some extent captures the tenant quality. We also follow Lu-Andrews (2017) and Liu et al. (2019) to compute the Altman Z-score $(A L T M A N)$ as a more precise measure of the tenant quality. To do so, we manually identify the public tenants for each REIT and collect the firm-level financial data for all public tenants from DataStream. For a given tenant in a certain year, the Altman Z-score is calculated as Eq. (5):

$$
\operatorname{ALTMAN}_{l, y}=1.2 \frac{C A_{l, y}-C L_{l, y}}{T A_{l, y}}+1.4 \frac{R E_{l, y}}{T A_{l, y}}+3.3 \frac{E B I T_{l, y}}{T A_{l, y}}+0.6 \frac{B V_{l, y}}{T L_{l, y}}+0.999 \frac{S A L E S_{l, y}}{T A_{l, y}},
$$

where $A L T M A N_{l, y}$ is the final Z-score for tenant $l$ in year $y$; for tenant $l$ in year $y, C A_{l, y}$ is the current assets; $C L_{l, y}$ is the current liabilities; $R E_{l, y}$ is the retained earnings; $E B I T_{l, y}$ is the earnings before interests and tax; $B V_{l, y}$ is the book value; $S A L E S_{l, y}$ is the sales revenue; $T A_{l, y}$ is the total assets; and $T L_{l, y}$ is the total liabilities. We then calculate the revenue weighted average Altman Z-score for each REIT as Eq. (6):

$$
\operatorname{ALTMAN}_{i, y}=\sum_{l=1}^{L} H_{i, l, y} \operatorname{ALTMAN}_{l, y}
$$

where $A L T M A N_{i, y}$ is the Altman Z-score for REIT $i$ in year $y$ and $H_{i, l, y}$ is the revenue share of tenant $l$ as defined in Eq. (1).

We control for other firm characteristics as follows: the firm size defined as the log of the market capitalization (SIZE), the financial leverage defined as the total debt divided by the book value of equity $(D / E)$, the growth rate of the real estate investments (GROWTH) defined as the annual growth of the real estate investment assets. When it comes to REIT performance studies, it is essential to account for the portfolio's metropolitan statistical area (MSA) geography as the risk is different across various geographic areas. It has been widely recorded by the literature and the industry that gateway MSAs often present investment advantages, hence are sought after by the investors. To control for the extent to which a REIT allocates its assets in major gateway MSAs, we calculate its total share of real estate assets in the 25 gateway MSAs (25MSA) as defined by Ling et al. (2018a). ${ }^{2}$ We also control for REIT type fixed effect. ${ }^{3}$

Table 1 presents the summary statistics for all the variables over our sample period between 2003 and 2015. The average tenant concentration (HHI_Tenant) is 0.13 with a standard deviation of 0.13 , close to the geographic concentration (HHI_Geo). The property type concentration is much higher with an average HHI_Type of 0.62, which is expected

\footnotetext{
${ }^{2}$ We follow Ling et al. (2018a) and define the 25 MSAs as Atlanta, Boston, Chicago, Dallas, Denver, Detroit, Houston, Indianapolis, Kansas City, Los Angeles, Miami, Minneapolis, New York, Orlando, Philadelphia, Phoenix, Portland, Sacramento, Saint Louis, San Antonio, San Diego, San Francisco, Seattle, Tampa, and Washington, D.C.

3 We categorize our sample into Diversified, Office, Industrial and Retail REITs.
} 
Table 1 Summary Statistics

\begin{tabular}{|c|c|c|c|c|c|}
\hline & Mean & Median & Std & Max & Min \\
\hline \multicolumn{6}{|c|}{ Performance measures (Scaled by Total Assets) } \\
\hline RENT & 0.093 & 0.090 & 0.025 & 0.150 & 0.024 \\
\hline NOI & 0.036 & 0.036 & 0.020 & 0.101 & 0.000 \\
\hline OPCOST & 0.089 & 0.088 & 0.022 & 0.156 & 0.041 \\
\hline$G \& A$ & 0.010 & 0.008 & 0.007 & 0.064 & 0.000 \\
\hline INTEREST & 0.025 & 0.026 & 0.009 & 0.048 & 0.000 \\
\hline$F F O$ & 0.055 & 0.051 & 0.025 & 0.140 & -0.026 \\
\hline \multicolumn{6}{|l|}{ Valuation measures } \\
\hline$P / F F O$ & 2.544 & 2.590 & 0.426 & 4.086 & 0.636 \\
\hline$M / B$ & 1.310 & 1.165 & 0.814 & 4.363 & 0.035 \\
\hline$Q$ & 2.040 & 1.876 & 0.955 & 6.895 & 0.346 \\
\hline \multicolumn{6}{|c|}{ Concentration measures } \\
\hline HHI_Tenant & 0.128 & 0.081 & 0.127 & 1.000 & 0.037 \\
\hline HHI_Geo & 0.154 & 0.081 & 0.201 & 0.944 & 0.009 \\
\hline HHI_Type & 0.622 & 0.599 & 0.208 & 1.000 & 0.211 \\
\hline \multicolumn{6}{|c|}{ Tenant characteristics } \\
\hline LEASE & 0.110 & 0.111 & 0.045 & 0.332 & 0.000 \\
\hline$A L T M A N$ & 1.982 & 2.025 & 1.631 & 12.349 & -2.090 \\
\hline \multicolumn{6}{|l|}{ Firm characteristics } \\
\hline SIZE (\$ Billion) & 3.450 & 2.498 & 3.773 & 44.918 & 1.003 \\
\hline$D / E$ & 1.419 & 1.229 & 1.237 & 14.211 & 0.000 \\
\hline GROWTH & 0.116 & 0.051 & 0.240 & 1.694 & -0.202 \\
\hline $25 M S A$ & 0.477 & 0.464 & 0.155 & 0.851 & 0.111 \\
\hline TURNOVER & 1.994 & 1.533 & 1.425 & 10.673 & 0.103 \\
\hline DIVGROWTH & 0.021 & 0.026 & 0.180 & 1.138 & -1.357 \\
\hline
\end{tabular}

This table presents descriptive statistics of the operating performance, market valuations and concentration measures of the tenant base, property locations and property types as well as the tenant and firm characteristics for the full sample of equity REITs during the 20032015 sample period. The operating performance measures include the gross rental income (REIT), net operating income (NOI), propertylevel aggregated operating expenses (OPCOST), general and administrative expenses $(G \& A)$, interest expenses (INTEREST), and funds from operations $(F F O)$, all presented as a share of the total assets. Market valuations include price-to-FFO $(P / F F O)$, market-to-book value $(M / B)$ and Tobins $\mathrm{Q}(Q)$. The tenant concentration is measured by the Herfindahl index based on the rental avenue attributed to each tenant (HHI_Tenant). The geographic and property-type concentration is also measured by the Herfindahl index (HHI_Geo and HHI_Type respectively) based on the shares of assets across MSAs and property types respectively. LEASE measures the long-term lease which is the share of base rents to be received from operating leases expiring during the sixth and thereafter fiscal years following the current fiscal year. ALTMAN is the Altman Z-score for the tenant quality. SIZE is the market capitalization of the REIT company, log-transformed in the regressions. $D / E$ is the financial leverage defined as the total debt divided by the book value of equity. GROWTH is the growth rate of the real estate investments. 25MSA is the total share of properties located in MSA regions. TURNOVER is the total value of the trading volume of a company for a given year divided by the end-of-year outstanding value of the common stocks. DIVGROWTH IS the dividend growth rate 
given that US REITs are known for their asset specialization. Our sample reports an average Altman Z-score (ALTMAN) of 2, which is within a normal range (Liu et al. 2019). On average, $11 \%$ of the total operating leases have a mid- or long-term maturity that is longer than 5 years. ${ }^{4}$

We test our hypotheses by using a series of two-stage Fama and MacBeth regressions (Fama and MacBeth 1973) to allow the estimates to vary over time. In the first stage, for each year of our sample period, we estimate the following cross-sectional regression:

$$
y_{i, t}=\gamma_{i} H H I \_ \text {Tenant }_{i, t-1}+\sum_{m=1}^{M} c_{i, m} X_{m, i, t-1}+e_{i, t},
$$

where $y_{i, t}$ represents one of the dependent variables for the operating performance and market valuations. HHI_Tenant ${ }_{i, t-1}$ is the Herfindahl index for tenant concentration, while $X_{m, i, t-1}$ represent the control variables for tenant and firm characteristics.

In the second stage, we use the time series of the regression coefficients and test if the average coefficient is significantly different from zero. To take into account serial correlation in the coefficient estimates, we follow Ang et al. (2006) and compute Newey and West (1987) standard errors with four lags in the second stage. ${ }^{5}$

\section{Main results}

\subsection{Tenant concentration and REIT operating performance}

We firstly test the impact of tenant concentration on operating performance measures and the results are reported in Table 2. HHI_Tenant has returned positive coefficients on both RENT and NOI with a significance level of 5\% and $1 \%$ respectively. A one standard deviation increase in the level of tenant concentration results in a $18.5 \%$ standard deviation increase in the NOI, ${ }^{6}$ indicating that, for a REIT company, the benefits associated with a concentrated tenant base outweigh the potentially disadvantaged negotiation power over the rental rates. We find a strongly negative impact of HHI_Tenant on both $G \& A$ and INTEREST that a one standard deviation increase in the level of tenant concentration is associated with a $35.4 \%$ and a $16.2 \%$ standard deviation decrease in the management costs and financial expenses respectively, supporting our argument that a more concentrated tenant base presents lower valuation uncertainty for creditors who will in turn charge lower interest rates. As a result of the positive effect on property-level cash flows and the negative effect on expenses, Model 6 has returned a significantly positive coefficient of HHI_Tenant on $F F O$, suggesting that REITs with a more concentrated tenant base on average present higher corporate cash flows. This result is also economically significant that a one standard deviation increase in the level of tenant concentration leads to a $30.6 \%$ standard deviation increase in FFO.

We find that both longer lease maturity and better tenant quality result in higher property operating costs (Model 3), implying that the long-term good-quality tenants need

\footnotetext{
${ }^{4}$ In the "Appendix", we present the correlation matrix of all the variables used in this study. We can see that our specification does not suffer from multicollinearity.

5 The results based on the standard errors with one to four lags are robust.

6 As HHI measures cannot be interpreted directly, the economic impact is calculated as the coefficient multiplied by the standard deviation of the tenant concentration and then divided by the standard deviation of the NOI to total asset. For other variables, the economic impact is calculated in the same way.
} 


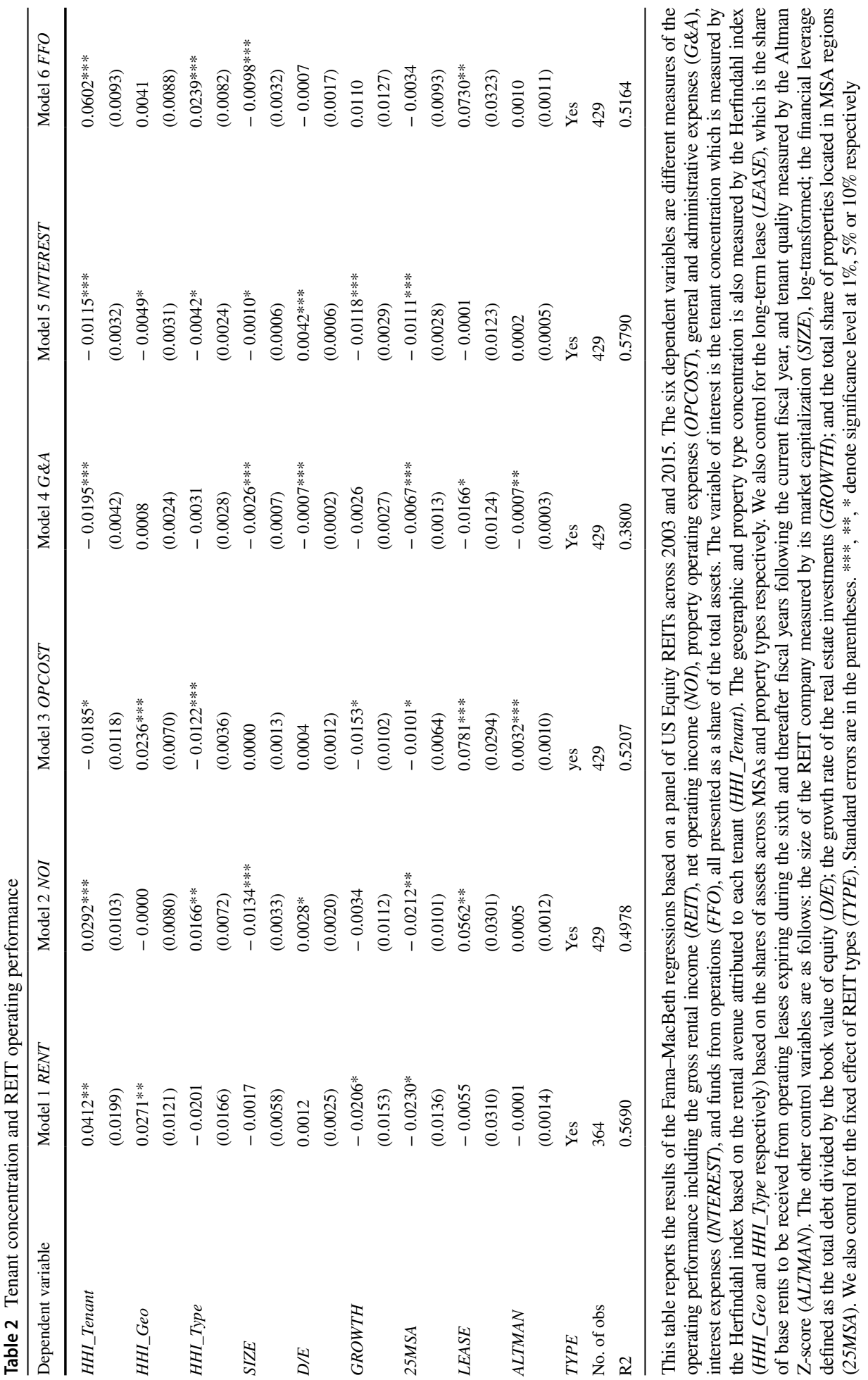


better service and maintenance at the building level, which is in line with the argument that major concentrated customers can be costly to suppliers (Kwak and Kim 2020). Meanwhile, we find that long-term leases and good tenant quality are associated with lower corporate-level management costs $(G \& A)$, supporting the argument that suppliers can benefit from increased operation efficiency with a concentrated customer base (Kwak and Kim 2020).

We find a positive coefficient of HHI_Geo on RENT, suggesting that REITs with more geographically concentrated portfolios present higher gross rental incomes. One possible explanation is that when REITs locate assets in a concentrated area they can develop regional specialism which helps them to negotiate better rental rates. We find that more geographically concentrated REITs incur more property-level operating expenses (Model 3 Table 2), which seems counterintuitive. However, this relationship is reversed and geographic concentration leads to lower property-level operating expenses after we correct for the selection bias (Model 3 Table 4). Feng et al. (2019) find that the operation efficiency decreases with increasing geographic concentration for more transparent REITs and a reverse relationship is recorded for less transparent REITs. Give the potential selection bias in our sample that larger and more transparent REITs tend to voluntarily report tenant information, the results in Tables 2 and 4 support this nonlinear relation between geographic concentration and REIT operation efficiency documented by Feng et al. (2019).

The impact of HHI_Type on NOI and FFO is significantly positive (see Model 3 and 5), suggesting that both operating costs and financial expenses are lower for REITs with a higher property type concentration, consistent with Capozza and Seguin (1999) who argue that property type concentration provides a simpler and more transparent asset base to manage and value.

Interestingly, we find that the share of investments in gateway MSA locations are negatively associated with property-level cash flows, management costs and financial expenses, implying that although on one hand the enhanced information about the core markets reduces the costs, on the other hand, the increased competition in the core markets squeezes the cash flows. As a trade-off, we find that REITs investing more on the core markets do not generate higher cash flows at the corporate level.

\subsection{Tenant concentration and REIT valuation}

We then examine how tenant concentration affects REIT value and the results are presented in Model 1 to 3 of Table 3. The coefficients of HHI_Tenant on all three valuation measures are negative with a $5 \%$ significance level, which is in sharp contrast to the majority of the empirical studies which support a positive relationship between corporate focus and value. This result is also economically significant that one standard deviation increase in tenant 
Table 3 Tenant concentration, liquidity, growth and valuation

\begin{tabular}{|c|c|c|c|c|c|}
\hline Dependent variable & Model $1 P / F F O$ & Model 2M/B & Model $3 Q$ & $\begin{array}{l}\text { Model } 4 \text { TURNO- } \\
V E R\end{array}$ & $\begin{array}{l}\text { Model } \\
5 \text { DIV- } \\
\text { GROWTH }\end{array}$ \\
\hline HHI_Tenant & $\begin{array}{l}-0.8706^{* *} \\
(0.3794)\end{array}$ & $\begin{array}{l}-0.9094 * * \\
(0.5061)\end{array}$ & $\begin{array}{l}-1.6916^{* *} \\
(0.7679)\end{array}$ & $\begin{array}{l}-1.2981 * * * \\
(0.3601)\end{array}$ & $\begin{array}{l}-0.1287 * * \\
(0.0637)\end{array}$ \\
\hline HHI_Geo & $\begin{array}{l}0.3132 \\
(0.3003)\end{array}$ & $\begin{array}{l}0.1099 \\
(0.2116)\end{array}$ & $\begin{array}{l}-0.3657 * \\
(0.2142)\end{array}$ & $\begin{array}{l}-0.0384 \\
(0.1088)\end{array}$ & $\begin{array}{l}0.0724 \\
(0.0682)\end{array}$ \\
\hline HHI_Type & $\begin{array}{l}0.2374 * * * \\
(0.0675)\end{array}$ & $\begin{array}{l}0.6115^{* * *} \\
(0.2027)\end{array}$ & $\begin{array}{l}1.0905 * * * \\
(0.3253)\end{array}$ & $\begin{array}{l}0.6797 * \\
(0.4258)\end{array}$ & $\begin{array}{l}0.0757 \\
(0.0871)\end{array}$ \\
\hline SIZE & $\begin{array}{l}0.1252^{* *} \\
(0.0600)\end{array}$ & $\begin{array}{l}0.2470^{* * *} \\
(0.0729)\end{array}$ & $\begin{array}{l}0.2319 \\
(0.1839)\end{array}$ & $\begin{array}{l}0.2871 * \\
(0.1685)\end{array}$ & $\begin{array}{l}-0.0247 \\
(0.0339)\end{array}$ \\
\hline$D / E$ & $\begin{array}{l}-0.0829 * * \\
(0.0349)\end{array}$ & $\begin{array}{l}0.2692 * * * \\
(0.0683)\end{array}$ & $\begin{array}{l}0.0422 \\
(0.0488)\end{array}$ & $\begin{array}{l}0.0961 * * \\
(0.0405)\end{array}$ & $\begin{array}{l}-0.0003 \\
(0.0082)\end{array}$ \\
\hline GROWTH & $\begin{array}{l}0.3255^{* *} \\
(0.1685)\end{array}$ & $\begin{array}{l}0.6204 \\
(0.5412)\end{array}$ & $\begin{array}{l}1.1647 * * * \\
(0.4347)\end{array}$ & $\begin{array}{l}0.1405 \\
(0.1969)\end{array}$ & $\begin{array}{l}-0.0173 \\
(0.0740)\end{array}$ \\
\hline $25 M S A$ & $\begin{array}{l}-0.0584 \\
(0.1740)\end{array}$ & $\begin{array}{l}0.0941 \\
(0.2212)\end{array}$ & $\begin{array}{l}0.3672 \\
(0.3739)\end{array}$ & $\begin{array}{l}-0.5916 * * * \\
(0.2262)\end{array}$ & $\begin{array}{l}-0.0325 \\
(0.0660)\end{array}$ \\
\hline LEASE & $\begin{array}{l}-1.0411 \\
(1.1398)\end{array}$ & $\begin{array}{l}3.5206^{* * * *} \\
(0.8136)\end{array}$ & $\begin{array}{l}-0.6568 \\
(1.6548)\end{array}$ & $\begin{array}{l}1.4587 \\
(1.6425)\end{array}$ & $\begin{array}{l}0.1577 \\
(0.3970)\end{array}$ \\
\hline$A L T M A N$ & $\begin{array}{l}0.0140 \\
(0.0181)\end{array}$ & $\begin{array}{l}0.0053 \\
(0.0274)\end{array}$ & $\begin{array}{l}-0.0086 \\
(0.0480)\end{array}$ & $\begin{array}{l}-0.0307 \\
(0.0257)\end{array}$ & $\begin{array}{l}0.0056 \\
(0.0061)\end{array}$ \\
\hline TYPE & Yes & Yes & Yes & Yes & Yes \\
\hline No. of obs & 393 & 422 & 428 & 412 & 398 \\
\hline $\mathrm{R} 2$ & 0.6661 & 0.6233 & 0.6437 & 0.8539 & 0.5359 \\
\hline
\end{tabular}

This table reports the results of the Fama-MacBeth regressions based on a panel of US Equity REITs across 2003 and 2015. The dependent variables are three different valuation measures including price-toFFO (P/FFO), market-to-Book value (M/B) and Tobin's $\mathrm{Q}(Q)$, as well as two determinants for the discount factor including the turnover which is the total value of the trading volume of a company for a given year divided by the end-of-year outstanding value of the common stocks (TURNOVER) and the dividend growth rate $(D I V G R O W T H)$. The variable of interest is the tenant concentration which is measured by the Herfindahl index based on the rental avenue attributed to each tenant (HHI_Tenant). The geographic and property type concentration is also measured by the Herfindahl index (HHI_Geo and HHI_Type respectively) based on the shares of assets across MSAs and property types respectively. We also control for the long-term lease $(L E A S E)$, which is the share of base rents to be received from operating leases expiring during the sixth and thereafter fiscal years following the current fiscal year, and the tenant quality measured by the Altman Z-score (ALTMAN). The other control variables are as follows: the size of the REIT company measured by its market capitalization $(S I Z E)$, log-transformed; the financial leverage defined as the total debt divided by the book value of equity $(D / E)$; the growth rate of the real estate investments $(G R O W T H)$; and the total share of properties located in MSA regions (25MSA). We also control for the fixed effect of REIT types (TYPE). Standard errors are in the parentheses. ***, **, * denote significance level at $1 \%, 5 \%$ or $10 \%$ respectively

concentration is associated with a $26.9 \%, 14.2 \%$ and $22.5 \%$ standard deviation decrease in $P / F F O, M / B$ and $Q$ values respectively. For property type concentration, we indeed identify a diversification discount effect that REITs with more concentrated asset types experience higher market valuations than their diversified rivals, consistent with previous empirical studies (Capozza and Seguin 1999; Cronqvist et al. 2001; Campbell et al. 2003; Ro and Ziobrowski 2012; García and Norli 2012). 
Table 4 Heckman two-stage regressions on operating performance

\begin{tabular}{|c|c|c|c|c|c|c|c|}
\hline \multirow{2}{*}{$\begin{array}{l}\text { Dependent } \\
\text { variable }\end{array}$} & \multirow[t]{2}{*}{ Stage 1} & \multicolumn{6}{|l|}{ Stage 2} \\
\hline & & $\begin{array}{l}\text { Model } 1 \\
\text { RENT }\end{array}$ & $\begin{array}{l}\text { Model } 2 \\
\text { NOI }\end{array}$ & $\begin{array}{l}\text { Model } 3 \\
\text { OPCOST }\end{array}$ & $\begin{array}{l}\text { Model } 4 \\
G \& A\end{array}$ & $\begin{array}{l}\text { Model } 5 \text { INTER- } \\
\text { EST }\end{array}$ & $\begin{array}{l}\text { Model } 6 \\
F F O\end{array}$ \\
\hline \multirow[t]{2}{*}{ IM Ratio } & & -0.0195 & 0.0179 & $0.1220^{* *}$ & -0.0080 & 0.0084 & $0.1216^{* *}$ \\
\hline & & $(0.1177)$ & $(0.0476)$ & $(0.0566)$ & $(0.0115)$ & $(0.0399)$ & $(0.0692)$ \\
\hline \multirow[t]{2}{*}{ HHI_Tenant } & & $0.0730^{* *}$ & -0.0080 & $0.0264 * *$ & $-0.0244 * * *$ & $-0.0083^{* *}$ & $0.0591 * * *$ \\
\hline & & $(0.0299)$ & $(0.0166)$ & $(0.0104)$ & $(0.0054)$ & $(0.0047)$ & $(0.0106)$ \\
\hline \multirow[t]{2}{*}{ HHI_Geo } & $-1.2852^{* * *}$ & 0.0237 & $0.0210^{* * *}$ & $-0.0183^{*}$ & -0.0016 & -0.0045 & -0.0122 \\
\hline & $(0.2217)$ & $(0.0183)$ & $(0.0077)$ & $(0.0109)$ & $(0.0044)$ & $(0.0050)$ & $(0.0138)$ \\
\hline \multirow[t]{2}{*}{ HHI_Type } & $-1.0673^{* * *}$ & -0.0218 & $-0.0205^{* *}$ & 0.0020 & 0.0011 & -0.0049 & 0.0058 \\
\hline & $(0.2063)$ & $(0.0227)$ & $(0.0092)$ & $(0.0091)$ & $(0.0040)$ & $(0.0084)$ & $(0.0144)$ \\
\hline \multirow[t]{2}{*}{ SIZE } & $0.3155^{* * *}$ & 0.0008 & 0.0006 & $-0.0130^{* * *}$ & $-0.0036^{* * *}$ & $-0.0034 * *$ & $-0.0060^{* *}$ \\
\hline & $(0.0507)$ & $(0.0070)$ & $(0.0043)$ & $(0.0040)$ & $(0.0011)$ & $(0.0014)$ & $(0.0027)$ \\
\hline \multirow[t]{2}{*}{$D / E$} & 0.0076 & 0.0035 & 0.0019 & $0.0028^{* *}$ & $-0.0005^{*}$ & $0.0046^{* * *}$ & -0.0013 \\
\hline & $(0.0413)$ & $(0.0032)$ & $(0.0018)$ & $(0.0015)$ & $(0.0004)$ & $(0.0007)$ & $(0.0014)$ \\
\hline \multirow[t]{2}{*}{ GROWTH } & 0.2269 & -0.0227 & $-0.0220 * *$ & -0.0115 & -0.0025 & $-0.0117 * * *$ & 0.0027 \\
\hline & $(0.5636)$ & $(0.0177)$ & $(0.0117)$ & $(0.0117)$ & $(0.0030)$ & $(0.0035)$ & $(0.0130)$ \\
\hline \multirow[t]{2}{*}{$25 M S A$} & $0.5140 *$ & -0.0231 & 0.0010 & $-0.0135^{*}$ & $-0.0069^{* *}$ & $-0.0159 * * *$ & 0.0093 \\
\hline & $(0.3648)$ & $(0.0191)$ & $(0.0117)$ & $(0.0093)$ & $(0.0027)$ & $(0.0055)$ & $(0.0101)$ \\
\hline \multirow[t]{2}{*}{ LEASE } & & -0.0176 & $0.0610^{*}$ & $0.0579 * *$ & $-0.0274^{*}$ & -0.0003 & $0.0856^{* *}$ \\
\hline & & $(0.0591)$ & $(0.0396)$ & $(0.0302)$ & $(0.0167)$ & $(0.0142)$ & $(0.0341)$ \\
\hline \multirow[t]{2}{*}{ ALTMAN } & & 0.0017 & $0.0033^{* * *}$ & 0.0008 & $-0.0005^{*}$ & $0.0006^{*}$ & 0.0008 \\
\hline & & $(0.0017)$ & $(0.0011)$ & $(0.0012)$ & $(0.0003)$ & $(0.0004)$ & $(0.0009)$ \\
\hline TYPE & Yes & Yes & Yes & Yes & Yes & Yes & Yes \\
\hline No. of obs & 1135 & 334 & 410 & 410 & 410 & 410 & 410 \\
\hline R2 & 0.3091 & 0.6517 & 0.5588 & 0.5827 & 0.4275 & 0.6453 & 0.5922 \\
\hline
\end{tabular}

This table reports the results of the Heckman two-stage regressions based on a panel of US Equity REITs across 2003 and 2015, where the first stage estimates the probability of a REIT reporting its tenant information. The six dependent variables are different measures of the operating performance including the gross rental income $(R E I T)$, net operating income $(N O I)$, property operating expenses (OPCOST), general and administrative expenses $(G \& A)$, interest expenses (INTEREST), and funds from operations $(F F O)$, all presented as a share of the total assets. The variable of interest is the tenant concentration which is measured by the Herfindahl index based on the rental avenue attributed to each tenant (HHI_Tenant). The geographic and property type concentration is also measured by the Herfindahl index (HHI_Geo and HHI_Type respectively) based on the shares of assets across MSAs and property types respectively. We also control for the long-term lease ( $L E A S E)$, which is the share of base rents to be received from operating leases expiring during the sixth and thereafter fiscal years following the current fiscal year, and tenant quality measured by the Altman Z-score (ALTMAN). The other control variables are as follows: the size of the REIT company measured by its market capitalization $(S I Z E)$, log-transformed; the financial leverage defined as the total debt divided by the book value of equity $(D / E)$; the growth rate of the real estate investments $(G R O W T H)$; and the total share of properties located in MSA regions (25MSA). We also control for the fixed effect of REIT types (TYPE). Standard errors are in the parentheses. ***, **, * denote significance level at $1 \%, 5 \%$ or $10 \%$ respectively

We argue that the concentration discount effect on valuation is channeled through the discount factor; and we expect a higher discount factor associated with a more concentrated tenant base which offsets the increased cash flows. The discount factor is essentially determined by the required return, which reflects the risk level, and the growth of a company. The seminal study by Amihud and Mendeison (1988) points out that a higher return is required for a higher liquidity risk. Capozza and Seguin (1999) follow their argument and use liquidity to capture the discount rate. We follow both studies and use the liquidity as 
a measure of the risk level. We also add the other important factor for the discount ratethe growth of REITs. We run regressions on the trading turnover (TURNOVER) and the dividend growth rate (DIVGROWTH) which are proxies for the liquidity risk and growth potentials respectively. The results are reported in Model 4 and 5 of Table 3 . We see that HHI_Tenant has a negative effect on TURNOVER, suggesting that REITs with a more concentrated tenant base experience a higher liquidity risk, hence a higher required return, consistent with Lee et al. (2020) who argue that a concentrated customer base increases the corporate risk. ${ }^{7}$ Meanwhile, tenant concentration negatively impacts on the dividend growth rate with a 5\% significance level. Overall, the discount factor for REITs with a concentrated tenant base shoots up as a result of the increased liquidity risk and decreased growth potentials, confirming our fourth hypothesis.

\section{Robustness tests}

\subsection{Selection bias}

We acknowledge that only about half of the REITs voluntarily report their tenants, which may raise concerns that our sample is not randomly distributed, i.e. larger or more transparent REITs are more likely to disclose their tenant information. To account for the potential selection bias, we conduct a Heckman correction based on a two-stage model: in the first stage, we estimate the probability of a REIT company reporting its tenant information by using a Probit model based on all US REITs during our sample period ${ }^{8}$; in the second stage, we add the inverse Mills (IM) ratio obtained from the first stage as an additional regressor in order to correct for the selection bias. This Heckman two-stage model is applied to all regressions on operating performance and market valuations, with results reported in Tables 4 and 5 respectively. As expected, we can see from the Stage 1 results that the probability of a REIT company reporting tenant information increases with the level of diversification and firm size. However, the correction term, IM Ratio, is mostly insignificant at Stage 2 except for Model 3 and 6 in Table 4, indicating a low likelihood of selection bias.

While most of the results remain similar in Table 4, we see some reversed results on NOI and operating expenses which is likely to be driven by the potential selection bias. Instead of a reduction in the operating costs (see Table 2), we now find that higher tenant concentration incurs higher operating costs at the property-level. One possible explanation is that the relation between concentration and operation efficiency is non-linear. While larger or more transparent REITs enjoy improved operation efficiency with a more concentrated tenant base, smaller or less transparent REITs need to put in more effort to provide quality service to major concentrated tenants, leading to increased operating costs. Similarly, as discussed above, the reversed effects of HHI_Geo on NOI and OPCOST also

\footnotetext{
7 To test whether the decreased liquidity is associated with the systematic or idiosyncratic risk, we test the impact of tenant concentration (HHI_Tenant) on the systematic and idiosyncratic risks of REITs which are calculated by using the Fama-French three-factor model. While we find no impact of HHI_Tenant on the systematic risk, we find a positive relation between tenant concentration and the idiosyncratic risk. This suggests that the liquidity risk associated with tenant concentration is unsystematic, which is expected as the tenant strategy is a company-specific operation and investment strategy. For parsimonious reasons, the results are not reported here.

${ }^{8}$ Given that S\&P Market Intelligence does not collect data on tenants for Multi-family and Hotel REITs, we exclude them from our first-stage estimations.
} 
Table 5 Heckman two-stage regressions on liquidity, growth and valuation

\begin{tabular}{|c|c|c|c|c|c|c|}
\hline \multirow{2}{*}{$\begin{array}{l}\text { Dependent } \\
\text { variable }\end{array}$} & \multirow[t]{2}{*}{ Stage 1} & \multicolumn{5}{|l|}{ Stage 2} \\
\hline & & $\begin{array}{l}\text { Model } 1 P / \\
F F O\end{array}$ & $\begin{array}{l}\text { Model } \\
2 \mathrm{M} / B\end{array}$ & Model $3 Q$ & $\begin{array}{l}\text { Model } 4 \\
\text { TURNOVER }\end{array}$ & $\begin{array}{l}\text { Model } 5 \text { DIV- } \\
G R O W T H\end{array}$ \\
\hline IM Ratio & & $\begin{array}{l}-0.6060 \\
(1.4396)\end{array}$ & $\begin{array}{l}2.8155 \\
(2.4637)\end{array}$ & $\begin{array}{l}-0.5402 \\
(1.3655)\end{array}$ & $\begin{array}{l}1.6027 \\
(1.3409)\end{array}$ & $\begin{array}{l}-0.1245 \\
(0.3338)\end{array}$ \\
\hline HHI_Tenant & & $\begin{array}{l}-1.4209 * * \\
(0.7317)\end{array}$ & $\begin{array}{l}-1.4327 * * \\
(0.6328)\end{array}$ & $\begin{array}{l}-2.2389 * * \\
(1.0547)\end{array}$ & $\begin{array}{l}-1.4146^{* * * *} \\
(0.2742)\end{array}$ & $\begin{array}{l}-0.0944 \\
(0.1217)\end{array}$ \\
\hline HHI_Geo & $\begin{array}{l}-1.2852^{* * * *} \\
(0.2217)\end{array}$ & $\begin{array}{l}0.0749 \\
(0.7248)\end{array}$ & $\begin{array}{l}-0.5462 * \\
(0.3624)\end{array}$ & $\begin{array}{l}-0.4981 * * \\
(0.2683)\end{array}$ & $\begin{array}{l}-0.2779 \\
(0.3352)\end{array}$ & $\begin{array}{l}0.1673 * \\
(0.1143)\end{array}$ \\
\hline HHI_Type & $\begin{array}{l}-1.0673 * * * \\
(0.2063)\end{array}$ & $\begin{array}{l}0.4715^{*} \\
(0.3141)\end{array}$ & $\begin{array}{l}0.2603 \\
(0.3867)\end{array}$ & $\begin{array}{l}1.3025 * * * \\
(0.4723)\end{array}$ & $\begin{array}{l}0.4410 \\
(0.6372)\end{array}$ & $\begin{array}{l}0.0728 \\
(0.1107)\end{array}$ \\
\hline SIZE & $\begin{array}{l}0.3155^{* * * *} \\
(0.0507)\end{array}$ & $\begin{array}{l}0.2441 * * \\
(0.1369)\end{array}$ & $\begin{array}{l}0.3356 * * * \\
(0.1038)\end{array}$ & $\begin{array}{l}0.0251 \\
(0.2275)\end{array}$ & $\begin{array}{l}0.3121 * * \\
(0.1473)\end{array}$ & $\begin{array}{l}-0.0622 \\
(0.0467)\end{array}$ \\
\hline$D / E$ & $\begin{array}{l}0.0076 \\
(0.0413)\end{array}$ & $\begin{array}{l}-0.0767 * \\
(0.0518)\end{array}$ & $\begin{array}{l}0.2726 * * * \\
(0.0782)\end{array}$ & $\begin{array}{l}0.0214 \\
(0.0644)\end{array}$ & $\begin{array}{l}0.0861 * * \\
(0.0403)\end{array}$ & $\begin{array}{l}-0.0112^{*} \\
(0.0082)\end{array}$ \\
\hline GROWTH & $\begin{array}{l}0.2269 \\
(0.5636)\end{array}$ & $\begin{array}{l}0.3739 * * \\
(0.2084)\end{array}$ & $\begin{array}{l}0.3938 \\
(0.5974)\end{array}$ & $\begin{array}{l}1.1123 * * \\
(0.4984)\end{array}$ & $\begin{array}{l}0.0507 \\
(0.2388)\end{array}$ & $\begin{array}{l}-0.0035 \\
(0.0663)\end{array}$ \\
\hline $25 M S A$ & $\begin{array}{l}0.5140 * \\
(0.3648)\end{array}$ & $\begin{array}{l}-0.2322 \\
(0.2630)\end{array}$ & $\begin{array}{l}0.6336^{*} \\
(0.4520)\end{array}$ & $\begin{array}{l}0.6454 \\
(0.7090)\end{array}$ & $\begin{array}{l}-0.5102^{* *} \\
(0.2396)\end{array}$ & $\begin{array}{l}0.0504 \\
(0.1093)\end{array}$ \\
\hline LEASE & & $\begin{array}{l}-1.8173 \\
(1.8665)\end{array}$ & $\begin{array}{l}2.7584 * * \\
(1.1238)\end{array}$ & $\begin{array}{l}-0.9003 \\
(1.9704)\end{array}$ & $\begin{array}{l}1.7934 \\
(2.0109)\end{array}$ & $\begin{array}{l}0.4990 \\
(0.4795)\end{array}$ \\
\hline ALTMAN & & $\begin{array}{l}0.0211 \\
(0.0200)\end{array}$ & $\begin{array}{l}0.0127 \\
(0.0467)\end{array}$ & $\begin{array}{l}-0.0335 \\
(0.0683)\end{array}$ & $\begin{array}{l}-0.0272 \\
(0.0252)\end{array}$ & $\begin{array}{l}-0.0006 \\
(0.0075)\end{array}$ \\
\hline TYPE & Yes & Yes & Yes & Yes & Yes & Yes \\
\hline No. of obs & 1135 & 374 & 404 & 409 & 393 & 379 \\
\hline $\mathrm{R} 2$ & 0.3091 & 0.7663 & 0.6655 & 0.6834 & 0.8798 & 0.5789 \\
\hline
\end{tabular}

This table reports the results of the Heckman two-stage regressions based on a panel of US Equity REITs across 2003 and 2015, where the first stage estimates the probability of a REIT reporting its tenant information. The dependent variables are three different valuation measures including price-to-FFO (P/FFO), market-to-Book value (M/B) and Tobin's $\mathrm{Q}(Q)$, as well as two determinants for the discount factor including the turnover which is the total value of the trading volume of a company for a given year divided by the end-of-year outstanding value of the common stocks (TURNOVER) and the dividend growth rate $(D I V G R O W T H)$. The variable of interest is the tenant concentration which is measured by the Herfindahl index based on the rental avenue attributed to each tenant (HHI_Tenant). The geographic and property type concentration is also measured by the Herfindahl index (HHI_Geo and HHI_Type respectively) based on the shares of assets across MSAs and property types respectively. We also control for the long-term lease (LEASE), which is the share of base rents to be received from operating leases expiring during the sixth and thereafter fiscal years following the current fiscal year, and the tenant quality measured by the Altman Z-score (ALTMAN). The other control variables are as follows: the size of the REIT company measured by its market capitalization $(S I Z E)$, log-transformed; the financial leverage defined as the total debt divided by the book value of equity $(D / E)$; the growth rate of the real estate investments $(G R O W T H)$; and the total share of properties located in MSA regions (25MSA). We also control for the fixed effect of REIT types (TYPE). Standard errors are in the parentheses. $* * *, * *, *$ denote significance level at $1 \%, 5 \%$ or $10 \%$ respectively

supports a non-linear relationship between geographic concentration and operation efficiency, consistent with Feng et al. (2019).

Compared to the baseline results in Table 2, we find that the impact of HHI_Type on NOI becomes negative. This reverse of relationship might be driven by the selection bias 
that "core" REITs investing in core property types (i.e. office, industrial, retail and residential) are more likely to report tenant information. While it falls beyond the scope of this study, the results in Tables 2 and 4 suggest that the research on the relation between asset type concentration and REIT performance needs to be updated given that, in recent years, many "non-core" REITs, which invest in cell towers, data centers, single-family rentals, and other "specialty" property types, have come to the market.

The results on market valuations and the determinants of the discount factor by using the Heckman two-stage regressions are presented in Table 5. We can see that they are largely consistent with the main results in Table 3, except for the dividend growth. While HHI_Tenant no longer impacts on DIVGROWTH (Model 5) after controlling for the selection bias, it still has a significantly negative impact on TURNOVER, which strengthens our argument that REITs with more concentrated tenant base experience higher liquidity risk which is then "punished" by the market valuations. Overall, we eliminate the concern that our results might be sizably affected by the potential selection bias.

\subsection{Focused versus diversified}

While we control for the exact level of asset type concentration by using the Herfindahl index as defined by Eq. 3 (HHI_Type), it is natural to question whether our results are driven by focused REITs only as focused REITs are more likely to have a more concentrated tenant base compared to diversified REITs. Following the REIT literature, focused REITs are defined as REITs solely investing in one type of property and diversified REITs are those investing in two or more types of properties. To test whether there is a systematic difference between diversified and focused REITs, we run all models on a sub-sample of focused REITs only. The results on the operating performance and market valuations are reported in Tables 6 and 7 respectively. Overall, the main results on operating and valuation measures do not change much. The coefficient of HHI_Tenant on OPCOST is largely improved to a significance level of $1 \%$, suggesting that the effect of a concentrated tenant base on property operating expenses is amplified if the REIT also adopts a focused strategy for its asset types. We also find that the lease term maturity no longer has an effect on corporate-level cash flows, implying that the long-term leases are more valuable for diversified REITs. We also run all regressions on a sub-sample of diversified REITs only and use Chow statistics to test the systematic difference between these two sub-samples. The result suggests that our findings are not driven by one group only and it is appropriate to treat our sample as a whole. Overall, we believe that our results are not driven by focused REITs only.

\subsection{Anchor tenant}

Liu and Liu (2013) record an amplification effect of the anchor tenants and find that the failure of an anchor tenant has a magnified impact on the REIT performance. If, however, the REIT has a diversified tenant base, its revenue exposure to the anchor tenant could be limited. Given that REITs adopting a more concentrated tenant base are more likely to have anchor tenants, it is sensible to raise concerns over whether our results are driven by a concentrated tenant base or the existence of anchor tenants. As an extra robustness test, we create a variable $(A N C H O R)$, which is the revenue share of the largest tenant of a given REIT, to control for the potential anchor tenant effect. The results on operating performance and market valuations are reported in Tables 8 and 9 


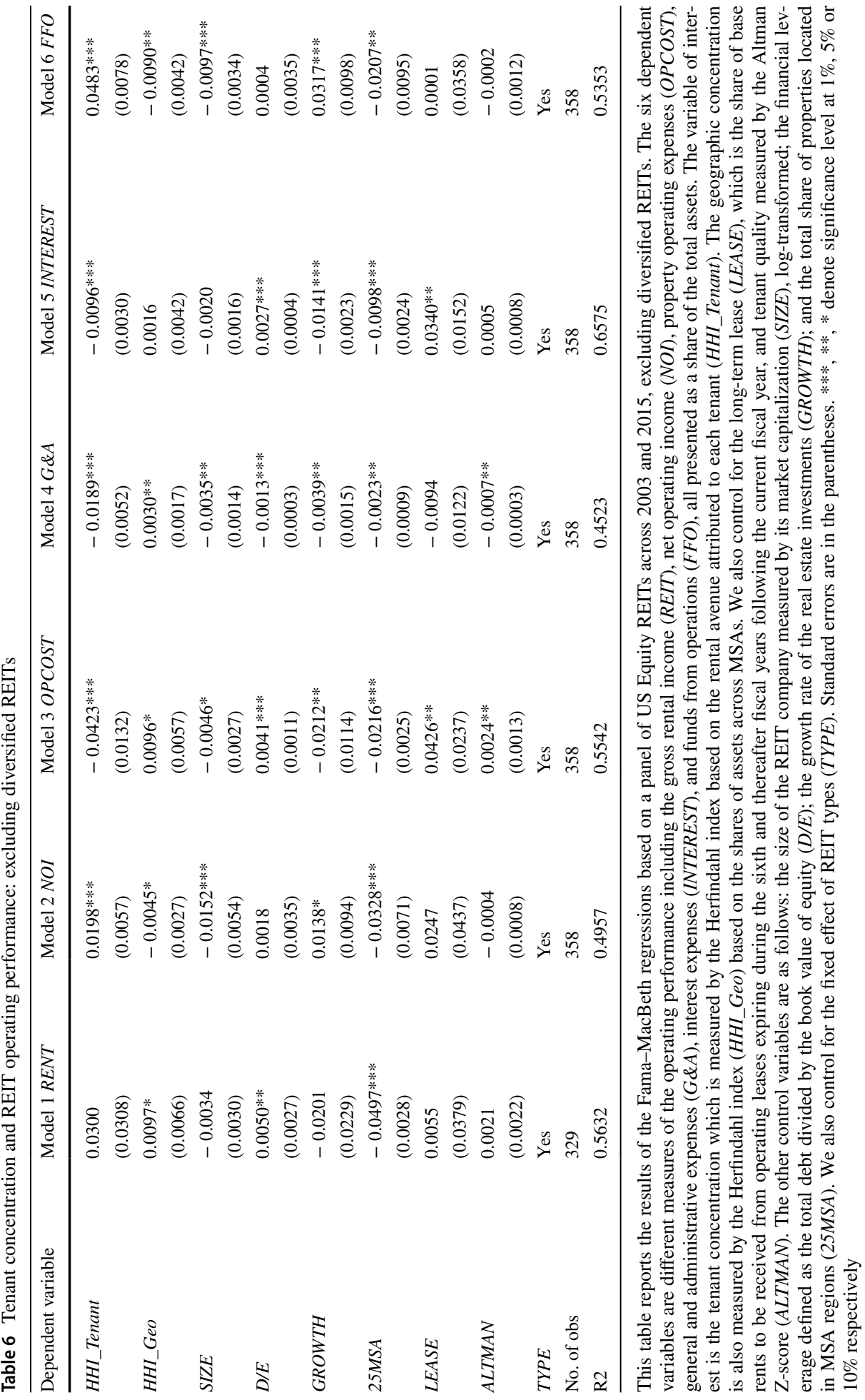


Table 7 Tenant concentration, liquidity, growth and valuation: excluding diversified REITs

\begin{tabular}{|c|c|c|c|c|c|}
\hline Dependent variable & Model $1 P / F F O$ & Model $2 \mathrm{M} / B$ & Model $3 Q$ & $\begin{array}{l}\text { Model } 4 \text { TURNO- } \\
V E R\end{array}$ & $\begin{array}{l}\text { Model } \\
5 \text { DIV- } \\
\text { GROWTH }\end{array}$ \\
\hline HHI_Tenant & $\begin{array}{l}-0.8862^{* *} \\
(0.4591)\end{array}$ & $\begin{array}{l}-1.1988 * \\
(0.7636)\end{array}$ & $\begin{array}{l}-1.0687 \\
(1.2807)\end{array}$ & $\begin{array}{l}-1.0861 * * * \\
(0.3632)\end{array}$ & $\begin{array}{l}-0.1134 * * * \\
(0.0388)\end{array}$ \\
\hline HHI_Geo & $\begin{array}{l}0.1947 \\
(0.3896)\end{array}$ & $\begin{array}{l}0.0074 \\
(0.2204)\end{array}$ & $\begin{array}{l}-0.1830 \\
(0.2135)\end{array}$ & $\begin{array}{l}0.3714 \\
(0.3022)\end{array}$ & $\begin{array}{l}0.0565 * * \\
(0.0261)\end{array}$ \\
\hline SIZE & $\begin{array}{l}0.1424 * \\
(0.0971)\end{array}$ & $\begin{array}{l}0.2304 * * \\
(0.1095)\end{array}$ & $\begin{array}{l}0.1111 \\
(0.2162)\end{array}$ & $\begin{array}{l}0.3576^{*} \\
(0.2629)\end{array}$ & $\begin{array}{l}0.0042 \\
(0.0324)\end{array}$ \\
\hline$D / E$ & $\begin{array}{l}-0.1319 * * * \\
(0.0413)\end{array}$ & $\begin{array}{l}0.2633 * * * \\
(0.0738)\end{array}$ & $\begin{array}{l}-0.1343^{*} \\
(0.0995)\end{array}$ & $\begin{array}{l}0.0205 \\
(0.0501)\end{array}$ & $\begin{array}{l}-0.0003 \\
(0.0134)\end{array}$ \\
\hline GROWTH & $\begin{array}{l}0.4550 * * * \\
(0.1365)\end{array}$ & $\begin{array}{l}1.0275 \\
(0.7962)\end{array}$ & $\begin{array}{l}1.3019 * * * \\
(0.3954)\end{array}$ & $\begin{array}{l}-0.0810 \\
(0.2417)\end{array}$ & $\begin{array}{l}-0.0448 \\
(0.0513)\end{array}$ \\
\hline $25 M S A$ & $\begin{array}{l}0.0195 \\
(0.2845)\end{array}$ & $\begin{array}{l}-0.1075 \\
(0.4628)\end{array}$ & $\begin{array}{l}0.8246 * \\
(0.5706)\end{array}$ & $\begin{array}{l}-0.2959 * \\
(0.1760)\end{array}$ & $\begin{array}{l}-0.0085 \\
(0.0467)\end{array}$ \\
\hline LEASE & $\begin{array}{l}-1.9350 \\
(1.7789)\end{array}$ & $\begin{array}{l}1.5709 * \\
(0.9351)\end{array}$ & $\begin{array}{l}-0.8402 \\
(1.5324)\end{array}$ & $\begin{array}{l}4.2401 * * \\
(2.2462)\end{array}$ & $\begin{array}{l}0.0839 \\
(0.2405)\end{array}$ \\
\hline$A L T M A N$ & $\begin{array}{l}0.0060 \\
(0.0159)\end{array}$ & $\begin{array}{l}-0.0036 \\
(0.0390)\end{array}$ & $\begin{array}{l}-0.0760 \\
(0.0947)\end{array}$ & $\begin{array}{l}-0.0625^{* * * *} \\
(0.0234)\end{array}$ & $\begin{array}{l}0.0157 * * * \\
(0.0057)\end{array}$ \\
\hline TYPE & Yes & Yes & Yes & Yes & Yes \\
\hline No. of obs & 330 & 351 & 357 & 346 & 334 \\
\hline $\mathrm{R} 2$ & 0.6591 & 0.6224 & 0.6378 & 0.8701 & 0.4380 \\
\hline
\end{tabular}

This table reports the results of the Fama-MacBeth regressions based on a panel of US Equity REITs across 2003 and 2015, excluding diversified REITs. The dependent variables are three different valuation measures including price-to-FFO (P/FFO), market-to-Book value (M/B) and Tobin's $\mathrm{Q}(Q)$, as well as two determinants for the discount factor including the turnover which is the total value of the trading volume of a company for a given year divided by the end-of-year outstanding value of the common stocks (TURNO$V E R)$ and the dividend growth rate (DIVGROWTH). The variable of interest is the tenant concentration which is measured by the Herfindahl index based on the rental avenue attributed to each tenant (HHI_Tenant). The geographic concentration is also measured by the Herfindahl index (HHI_Geo) based on the shares of assets across MSAs. We also control for the long-term lease (LEASE), which is the share of base rents to be received from operating leases expiring during the sixth and thereafter fiscal years following the current fiscal year, and the tenant quality measured by the Altman Z-score (ALTMAN). The other control variables are as follows: the size of the REIT company measured by its market capitalization $(S I Z E), \log -$ transformed; the financial leverage defined as the total debt divided by the book value of equity $(D / E)$; the growth rate of the real estate investments $(G R O W T H)$; and the total share of properties located in MSA regions (25MSA). We also control for the fixed effect of REIT types (TYPE). Standard errors are in the parentheses. $* * *, * *, *$ denote significance level at $1 \%, 5 \%$ or $10 \%$ respectively

respectively. HHI_Tenant no longer has an impact on RENT and NOI after including the anchor tenant effect, which supports the argument by Wheaton (2000) and Liu and Liu (2013) that the anchor or dominant tenants are more likely to pay lower base rents as a reward for their "brand" drawing power. However, as a concentrated tenant base is still associated with lower expenses (Model 4 and 5), the impact of tenant concentration on corporate cash flows remain significantly positive (Model 6). We can see from Table 9 that the coefficients of HHI_Tenant on all valuation measures remain significantly negative, strongly consistent with the main results in Table 3, reinforcing the concentration discount effect of the underlying tenants. Overall, we believe that our results on the tenant concentration are not driven by the anchor tenant effect. 
Table 8 Tenant concentration and REIT operating performance: anchor tenant effect

\begin{tabular}{|c|c|c|c|c|c|c|}
\hline $\begin{array}{l}\text { Dependent } \\
\text { variable }\end{array}$ & $\begin{array}{l}\text { Model } 1 \\
\text { RENT }\end{array}$ & Model $2 \mathrm{NOI}$ & $\begin{array}{l}\text { Model } 3 \\
\text { OPCOST }\end{array}$ & $\begin{array}{l}\text { Model } 4 \\
G \& A\end{array}$ & $\begin{array}{l}\text { Model } 5 \text { INTER- } \\
\text { EST }\end{array}$ & $\begin{array}{l}\text { Model } 6 \\
F F O\end{array}$ \\
\hline HHI_Tenant & $\begin{array}{l}0.0185 \\
(0.0271)\end{array}$ & $\begin{array}{l}0.0229 * \\
(0.0133)\end{array}$ & $\begin{array}{l}-0.0201 * \\
(0.0140)\end{array}$ & $\begin{array}{l}-0.0224 * * * \\
(0.0038)\end{array}$ & $\begin{array}{l}-0.0152 * * * \\
(0.0041)\end{array}$ & $\begin{array}{l}0.0605 * * * \\
(0.0123)\end{array}$ \\
\hline HHI_Geo & $\begin{array}{l}0.0227 * * \\
(0.0113)\end{array}$ & $\begin{array}{l}0.0020 \\
(0.0092)\end{array}$ & $\begin{array}{l}0.0256 * * * \\
(0.0076)\end{array}$ & $\begin{array}{l}0.0006 \\
(0.0026)\end{array}$ & $\begin{array}{l}-0.0044 * \\
(0.0032)\end{array}$ & $\begin{array}{l}0.0058 \\
(0.0104)\end{array}$ \\
\hline HHI_Type & $\begin{array}{l}-0.0056 \\
(0.0121)\end{array}$ & $\begin{array}{l}0.0201 * * \\
(0.0081)\end{array}$ & $\begin{array}{l}-0.0097 * * \\
(0.0039)\end{array}$ & $\begin{array}{l}-0.0031 \\
(0.0029)\end{array}$ & $\begin{array}{l}-0.0036^{*} \\
(0.0025)\end{array}$ & $\begin{array}{l}0.0269 * * * \\
(0.0094)\end{array}$ \\
\hline SIZE & $\begin{array}{l}-0.0010 \\
(0.0048)\end{array}$ & $\begin{array}{l}-0.0136 * * * \\
(0.0033)\end{array}$ & $\begin{array}{l}-0.0000 \\
(0.0013)\end{array}$ & $\begin{array}{l}-0.0026^{* * *} \\
(0.0007)\end{array}$ & $\begin{array}{l}-0.0011 * * \\
(0.0006)\end{array}$ & $\begin{array}{l}-0.0099 * * * \\
(0.0032)\end{array}$ \\
\hline$D / E$ & $\begin{array}{l}0.0020 \\
(0.0024)\end{array}$ & $\begin{array}{l}0.0026 \\
(0.0021)\end{array}$ & $\begin{array}{l}0.0003 \\
(0.0012)\end{array}$ & $\begin{array}{l}-0.0008 * * * \\
(0.0002)\end{array}$ & $\begin{array}{l}0.0041 * * * \\
(0.0006)\end{array}$ & $\begin{array}{l}-0.0008 \\
(0.0018)\end{array}$ \\
\hline GROWTH & $\begin{array}{l}-0.0308^{* *} \\
(0.0132)\end{array}$ & $\begin{array}{l}-0.0075 \\
(0.0098)\end{array}$ & $\begin{array}{l}-0.0169 * * \\
(0.0090)\end{array}$ & $\begin{array}{l}-0.0034 \\
(0.0027)\end{array}$ & $\begin{array}{l}-0.0132 * * * \\
(0.0037)\end{array}$ & $\begin{array}{l}0.0091 \\
(0.0115)\end{array}$ \\
\hline $25 M S A$ & $\begin{array}{l}-0.0358 * * * \\
(0.0112)\end{array}$ & $\begin{array}{l}-0.0230 * * \\
(0.0105)\end{array}$ & $\begin{array}{l}-0.0115^{* *} \\
(0.0063)\end{array}$ & $\begin{array}{l}-0.0067 * * * \\
(0.0013)\end{array}$ & $\begin{array}{l}-0.0111 * * * \\
(0.0028)\end{array}$ & $\begin{array}{l}-0.0052 \\
(0.0098)\end{array}$ \\
\hline LEASE & $\begin{array}{l}0.0152 \\
(0.0310)\end{array}$ & $\begin{array}{l}0.0633 * * \\
(0.0316)\end{array}$ & $\begin{array}{l}0.0824 * * * \\
(0.0300)\end{array}$ & $\begin{array}{l}-0.0175^{*} \\
(0.0129)\end{array}$ & $\begin{array}{l}0.0008 \\
(0.0119)\end{array}$ & $\begin{array}{l}0.0800 * * \\
(0.0342)\end{array}$ \\
\hline$A L T M A N$ & $\begin{array}{l}0.0004 \\
(0.0016)\end{array}$ & $\begin{array}{l}0.0003 \\
(0.0012)\end{array}$ & $\begin{array}{l}0.0031 * * * \\
(0.0011)\end{array}$ & $\begin{array}{l}-0.0008 * * * \\
(0.0003)\end{array}$ & $\begin{array}{l}0.0001 \\
(0.0005)\end{array}$ & $\begin{array}{l}0.0009 \\
(0.0012)\end{array}$ \\
\hline ANCHOR & $\begin{array}{l}0.0116^{* * * *} \\
(0.0044)\end{array}$ & $\begin{array}{l}-0.0092 \\
(0.0102)\end{array}$ & $\begin{array}{l}-0.0020 \\
(0.0072)\end{array}$ & $\begin{array}{l}0.0014 \\
(0.0015)\end{array}$ & $\begin{array}{l}0.0075 * * \\
(0.0038)\end{array}$ & $\begin{array}{l}-0.0180 * * \\
(0.0080)\end{array}$ \\
\hline TYPE & Yes & Yes & Yes & Yes & Yes & Yes \\
\hline No. of obs & 361 & 426 & 426 & 426 & 426 & 426 \\
\hline $\mathrm{R} 2$ & 0.5614 & 0.4904 & 0.5191 & 0.3919 & 0.5729 & 0.4925 \\
\hline
\end{tabular}

This table reports the results of the Fama-MacBeth regressions based on a panel of US Equity REITs across 2003 and 2015. The six dependent variables are different measures of the operating performance including the gross rental income $(R E I T)$, net operating income $(N O I)$, property operating expenses (OPCOST), general and administrative expenses $(G \& A)$, interest expenses (INTEREST), and funds from operations $(F F O)$, all presented as a share of the total assets. The variable of interest is the tenant concentration which is measured by the Herfindahl index based on the rental avenue attributed to each tenant (HHI_Tenant). The geographic and property type concentration is also measured by the Herfindahl index (HHI_Geo and HHI_Type respectively) based on the shares of assets across MSAs and property types respectively. We also control for the long-term lease (LEASE), which is the share of base rents to be received from operating leases expiring during the sixth and thereafter fiscal years following the current fiscal year, and tenant quality measured by the Altman Z-score (ALTMAN). Moreover, we control for the anchor tenant effect $(A N C H O R)$ which is the revenue share of the largest tenant for each REIT. The other control variables are as follows: the size of the REIT company measured by its market capitalization (SIZE), log-transformed; the financial leverage defined as the total debt divided by the book value of equity $(D / E)$; the growth rate of the real estate investments $(G R O W T H)$; and the total share of properties located in MSA regions (25MSA). We also control for the fixed effect of REIT types (TYPE). Standard errors are in the parentheses. $* * *, * *, *$ denote significance level at $1 \%, 5 \%$ or $10 \%$ respectively

\subsection{Alternative measure of tenant concentration}

We also test the appropriateness of our HHI measure of tenant concentration by replacing it with an alternative ad hoc measure which is the log-transformed number of tenants at REIT level (Tenant_No.). The results on operating performance and market valuations 
Table 9 Tenant concentration, liquidity, growth and valuation: anchor tenant effect

\begin{tabular}{|c|c|c|c|c|c|c|}
\hline \multirow{3}{*}{$\begin{array}{l}\text { Dependent vari- } \\
\text { able } \\
\text { HHI_Tenant }\end{array}$} & \multicolumn{2}{|c|}{ Model $1 P / F F O$} & \multirow{2}{*}{$\begin{array}{l}\text { Model } 2 \mathrm{M} / B \\
-1.1426^{* * *}\end{array}$} & \multirow{2}{*}{$\begin{array}{c}\text { Model } 3 Q \\
-2.0594 * *\end{array}$} & \multirow{3}{*}{$\begin{array}{l}\text { Model } 4 \text { TURNO- } \\
\text { VER } \\
-1.6941^{* * *} \\
(0.5369)\end{array}$} & \multirow{3}{*}{$\begin{array}{l}\text { Model } 5 \\
\text { DIV- } \\
\text { GROWTH } \\
0.0080 \\
(0.0882)\end{array}$} \\
\hline & $-1.0555^{* *}$ & & & & & \\
\hline & $(0.4934)$ & & $(0.4373)$ & $(0.8718)$ & & \\
\hline \multirow[t]{2}{*}{ HHI_Geo } & 0.2361 & & 0.1481 & $-0.3424 *$ & -0.0291 & 0.0826 \\
\hline & $(0.3786)$ & & $(0.2227)$ & $(0.2190)$ & $(0.1064)$ & $(0.0819)$ \\
\hline \multirow[t]{2}{*}{ HHI_Type } & $0.1477 * *$ & & $0.7224 * * *$ & $1.1342 * * *$ & $0.6678 *$ & 0.0762 \\
\hline & $(0.0843)$ & & $(0.2197)$ & $(0.3252)$ & $(0.4098)$ & $(0.0862)$ \\
\hline \multirow[t]{2}{*}{ SIZE } & $0.1381 * *$ & & $0.2502 * * *$ & 0.2369 & $0.2630 *$ & -0.0213 \\
\hline & $(0.0667)$ & & $(0.0730)$ & $(0.1830)$ & $(0.1576)$ & $(0.0367)$ \\
\hline \multirow[t]{2}{*}{$D / E$} & $-0.0895^{* *}$ & & $0.2733 * * *$ & 0.0455 & $0.0808 * *$ & 0.0055 \\
\hline & $(0.0370)$ & & $(0.0672)$ & $(0.0435)$ & $(0.0389)$ & $(0.0106)$ \\
\hline \multirow[t]{2}{*}{ GROWTH } & $0.3621 * *$ & & 0.6574 & $1.1666 * * *$ & -0.0374 & 0.0222 \\
\hline & $(0.1684)$ & & $(0.5555)$ & $(0.4369)$ & $(0.2123)$ & $(0.0465)$ \\
\hline \multirow[t]{2}{*}{$25 M S A$} & 0.0178 & & 0.0534 & 0.3756 & $-0.5871 * * *$ & -0.0436 \\
\hline & $(0.1604)$ & & $(0.2306)$ & $(0.3746)$ & $(0.2145)$ & $(0.0678)$ \\
\hline \multirow[t]{2}{*}{ LEASE } & -1.1105 & $3.6642 * * *$ & & -0.7929 & 1.4308 & 0.1204 \\
\hline & $(1.1602)$ & $(0.7502)$ & & $(1.6315)$ & $(1.5059)$ & $(0.4657)$ \\
\hline \multirow[t]{2}{*}{$A L T M A N$} & 0.0053 & & -0.0043 & -0.0204 & $-0.0411^{*}$ & $0.0089 *$ \\
\hline & $(0.0169)$ & & $(0.0307)$ & $(0.0460)$ & $(0.0292)$ & $(0.0064)$ \\
\hline \multirow[t]{2}{*}{$A N C H O R$} & $0.3230 *$ & & -0.3049 & 0.2648 & 0.5132 & -0.1687 \\
\hline & $(0.2030)$ & & $(0.3879)$ & $(0.2228)$ & $(0.4386)$ & $(0.1419)$ \\
\hline TYPE & Yes & & Yes & Yes & Yes & Yes \\
\hline No. of obs & 390 & & 419 & 425 & 409 & 395 \\
\hline $\mathrm{R} 2$ & 0.6810 & & 0.6375 & 0.6387 & 0.8580 & 0.5591 \\
\hline
\end{tabular}

This table reports the results of the Fama-MacBeth regressions based on a panel of US Equity REITs across 2003 and 2015. The dependent variables are three different valuation measures including price-toFFO (P/FFO), market-to-Book value (M/B) and Tobin's $\mathrm{Q}(Q)$, as well as two determinants for the discount factor including the turnover which is the total value of the trading volume of a company for a given year divided by the end-of-year outstanding value of the common stocks (TURNOVER) and the dividend growth rate $(D I V G R O W T H)$. The variable of interest is the tenant concentration which is measured by the Herfindahl index based on the rental avenue attributed to each tenant (HHI_Tenant). The geographic and property type concentration is also measured by the Herfindahl index (HHI_Geo and HHI_Type respectively) based on the shares of assets across MSAs and property types respectively. We also control for the long-term lease ( $L E A S E)$, which is the share of base rents to be received from operating leases expiring during the sixth and thereafter fiscal years following the current fiscal year, and the tenant quality measured by the Altman $\mathrm{Z}$-score $(A L T M A N)$. Moreover, we control for the anchor tenant effect $(A N C H O R)$ which is the revenue share of the largest tenant for each REIT. The other control variables are as follows: the size of the REIT company measured by its market capitalization (SIZE), log-transformed; the financial leverage defined as the total debt divided by the book value of equity $(D / E)$; the growth rate of the real estate investments $(G R O W T H)$; and the total share of properties located in MSA regions (25MSA). We also control for the fixed effect of REIT types (TYPE). Standard errors are in the parentheses. ***, **, * denote significance level at $1 \%, 5 \%$ or $10 \%$ respectively 
Table 10 Tenant concentration and REIT operating performance: number of tenants

\begin{tabular}{|c|c|c|c|c|c|c|}
\hline $\begin{array}{l}\text { Dependent } \\
\text { variable }\end{array}$ & $\begin{array}{l}\text { Model } 1 \\
\text { RENT }\end{array}$ & Model 2 NOI & $\begin{array}{l}\text { Model } 3 \\
\text { OPCOST }\end{array}$ & $\begin{array}{l}\text { Model } 4 \\
G \& A\end{array}$ & $\begin{array}{l}\text { Model 5INTER- } \\
\text { EST }\end{array}$ & Model $6 F F O$ \\
\hline Tenant_No & $\begin{array}{l}0.0015 \\
(0.0027)\end{array}$ & $\begin{array}{l}-0.0032 * * \\
(0.0014)\end{array}$ & $\begin{array}{l}0.0083 * * * \\
(0.0014)\end{array}$ & $\begin{array}{l}0.0016 * * \\
(0.0007)\end{array}$ & $\begin{array}{l}0.0024 * * * \\
(0.0007)\end{array}$ & $\begin{array}{l}-0.0071^{* * *} \\
(0.0014)\end{array}$ \\
\hline HHI_Geo & $\begin{array}{l}0.0132 * \\
(0.0086)\end{array}$ & $\begin{array}{l}0.0009 \\
(0.0072)\end{array}$ & $\begin{array}{l}0.0198 * * * \\
(0.0067)\end{array}$ & $\begin{array}{l}0.0011 \\
(0.0022)\end{array}$ & $\begin{array}{l}-0.0044 * \\
(0.0031)\end{array}$ & $\begin{array}{l}0.0042 \\
(0.0075)\end{array}$ \\
\hline HHI_Type & $\begin{array}{l}-0.0143 \\
(0.0158)\end{array}$ & $\begin{array}{l}0.0181 * * * \\
(0.0065)\end{array}$ & $\begin{array}{l}-0.0113^{* * *} \\
(0.0031)\end{array}$ & $\begin{array}{l}-0.0053^{* *} \\
(0.0028)\end{array}$ & $\begin{array}{l}-0.0051^{* *} \\
(0.0021)\end{array}$ & $\begin{array}{l}0.0285 * * * \\
(0.0079)\end{array}$ \\
\hline SIZE & $\begin{array}{l}-0.0021 \\
(0.0055)\end{array}$ & $\begin{array}{l}-0.0133 * * * \\
(0.0030)\end{array}$ & $\begin{array}{l}-0.0020^{*} \\
(0.0013)\end{array}$ & $\begin{array}{l}-0.0023^{* * * *} \\
(0.0007)\end{array}$ & $\begin{array}{l}-0.0012 * \\
(0.0007)\end{array}$ & $\begin{array}{l}-0.0098^{* * *} * \\
(0.0030)\end{array}$ \\
\hline$D / E$ & $\begin{array}{l}0.0043 \\
(0.0035)\end{array}$ & $\begin{array}{l}0.0028^{*} \\
(0.0019)\end{array}$ & $\begin{array}{l}0.0007 \\
(0.0011)\end{array}$ & $\begin{array}{l}-0.0008^{* * *} \\
(0.0002)\end{array}$ & $\begin{array}{l}0.0041^{* * *} \\
(0.0006)\end{array}$ & $\begin{array}{l}-0.0005 \\
(0.0016)\end{array}$ \\
\hline GROWTH & $\begin{array}{l}-0.0250 \\
(0.0189)\end{array}$ & $\begin{array}{l}-0.0022 \\
(0.0122)\end{array}$ & $\begin{array}{l}-0.0159^{* *} \\
(0.0081)\end{array}$ & $\begin{array}{l}-0.0034^{*} \\
(0.0022)\end{array}$ & $\begin{array}{l}-0.0129 * * * \\
(0.0036)\end{array}$ & $\begin{array}{l}0.0141 \\
(0.0145)\end{array}$ \\
\hline $25 M S A$ & $\begin{array}{l}-0.0295^{* *} \\
(0.0144)\end{array}$ & $\begin{array}{l}-0.0204^{* *} \\
(0.0098)\end{array}$ & $\begin{array}{l}-0.0112 * \\
(0.0067)\end{array}$ & $\begin{array}{l}-0.0043^{* *} \\
(0.0017)\end{array}$ & $\begin{array}{l}-0.0096^{* * * *} \\
(0.0023)\end{array}$ & $\begin{array}{l}-0.0065 \\
(0.0095)\end{array}$ \\
\hline LEASE & $\begin{array}{l}-0.0590^{*} \\
(0.0412)\end{array}$ & $\begin{array}{l}0.0416^{*} \\
(0.0287)\end{array}$ & $\begin{array}{l}0.0563 * * \\
(0.0278)\end{array}$ & $\begin{array}{l}-0.0143 \\
(0.0132)\end{array}$ & $\begin{array}{l}-0.0001 \\
(0.0133)\end{array}$ & $\begin{array}{l}0.0560 * * \\
(0.0296)\end{array}$ \\
\hline ALTMAN & $\begin{array}{l}0.0008 \\
(0.0022)\end{array}$ & $\begin{array}{l}0.0001 \\
(0.0011)\end{array}$ & $\begin{array}{l}0.0030^{* *} \\
(0.0012)\end{array}$ & $\begin{array}{l}-0.0007^{* *} \\
(0.0003)\end{array}$ & $\begin{array}{l}0.0000 \\
(0.0005)\end{array}$ & $\begin{array}{l}0.0008 \\
(0.0012)\end{array}$ \\
\hline TYPE & Yes & Yes & Yes & Yes & Yes & Yes \\
\hline No. of obs & 364 & 429 & 429 & 429 & 429 & 429 \\
\hline $\mathrm{R} 2$ & 0.5623 & 0.4856 & 0.5503 & 0.3527 & 0.5801 & 0.4904 \\
\hline
\end{tabular}

This table reports the results of the Fama-MacBeth regressions based on a panel of US Equity REITs across 2003 and 2015. The six dependent variables are different measures of the operating performance including the gross rental income (REIT), net operating income (NOI), property operating expenses (OPCOST), general and administrative expenses $(G \& A)$, interest expenses (INTEREST), and funds from operations $(F F O)$, all presented as a share of the total assets. We use an alternative measure to proxy for the tenant concentration which is the total number of tenants for each REIT (Tenant_No.). The geographic and property type concentration is also measured by the Herfindahl index (HHI_Geo and HHI_Type respectively) based on the shares of assets across MSAs and property types respectively. We also control for the long-term lease (LEASE), which is the share of base rents to be received from operating leases expiring during the sixth and thereafter fiscal years following the current fiscal year, and tenant quality measured by the Altman Z-score (ALTMAN). The other control variables are as follows: the size of the REIT company measured by its market capitalization (SIZE), log-transformed; the financial leverage defined as the total debt divided by the book value of equity $(D / E)$; the growth rate of the real estate investments (GROWTH); and the total share of properties located in MSA regions (25MSA). We also control for the fixed effect of REIT types (TYPE). Standard errors are in the parentheses. ***, **, * denote significance level at $1 \%, 5 \%$ or $10 \%$ respectively

are reported in Tables 10 and 11 respectively. As Tenant_No. is a diversification or dispersion measure, we expect the coefficients to be opposite to HHI_Tenant. We can see from Table 10 that the more tenants a REIT company has the higher expenses it incurs, hence the lower corporate-level cash flow it generates, which are consistent with the results on tenant concentration. However, we do not find any significant impact of tenant numbers on the valuation measures, implying that HHI is a better measure of the level of tenant concentration. Two REITs with the same number of tenants could present very different profiles of tenant concentration. 
Table 11 Tenant concentration, liquidity, growth and valuation: number of tenants

\begin{tabular}{|c|c|c|c|c|c|}
\hline Dependent variable & Model $1 P / F F O$ & Model $2 \mathrm{M} / B$ & Model $3 Q$ & $\begin{array}{l}\text { Model } 4 \text { TURNO- } \\
\text { VER }\end{array}$ & $\begin{array}{l}\text { Model } \\
5 \text { DIV- } \\
\text { GROWTH }\end{array}$ \\
\hline Tenant_No & $\begin{array}{l}0.1134 \\
(0.0916)\end{array}$ & $\begin{array}{l}0.0980 \\
(0.0946)\end{array}$ & $\begin{array}{l}0.0125 \\
(0.0292)\end{array}$ & $\begin{array}{l}-0.0225^{* *} \\
(0.0106)\end{array}$ & $\begin{array}{l}-0.0204^{*} \\
(0.0124)\end{array}$ \\
\hline HHI_Geo & $\begin{array}{l}0.2758 \\
(0.3383)\end{array}$ & $\begin{array}{l}0.1986 \\
(0.2257)\end{array}$ & $\begin{array}{l}-0.1200 * * * \\
(0.0420)\end{array}$ & $\begin{array}{l}-0.0231 * * \\
(0.0121)\end{array}$ & $\begin{array}{l}-0.0365^{* *} \\
(0.0148)\end{array}$ \\
\hline HHI_Type & $\begin{array}{l}0.0929 \\
(0.0735)\end{array}$ & $\begin{array}{l}0.4722 * * * \\
(0.1793)\end{array}$ & $\begin{array}{l}0.0076 \\
(0.0451)\end{array}$ & $\begin{array}{l}-0.0117 \\
(0.0129)\end{array}$ & $\begin{array}{l}-0.0030 \\
(0.0092)\end{array}$ \\
\hline$S I Z E$ & $\begin{array}{l}0.1303 * * * \\
(0.0474)\end{array}$ & $\begin{array}{l}0.2795 * * * \\
(0.0616)\end{array}$ & $\begin{array}{l}0.0514^{*} \\
(0.0369)\end{array}$ & $\begin{array}{l}-0.0123 \\
(0.0100)\end{array}$ & $\begin{array}{l}-0.0038 \\
(0.0145)\end{array}$ \\
\hline$D / E$ & $\begin{array}{l}-0.0841^{* *} \\
(0.0337)\end{array}$ & $\begin{array}{l}0.2461 * * * \\
(0.0704)\end{array}$ & $\begin{array}{l}0.0194 \\
(0.0173)\end{array}$ & $\begin{array}{l}0.0174 * * \\
(0.0088)\end{array}$ & $\begin{array}{l}0.0222 * * \\
(0.0120)\end{array}$ \\
\hline GROWTH & $\begin{array}{l}0.3116^{* *} \\
(0.1462)\end{array}$ & $\begin{array}{l}0.5355 \\
(0.5123)\end{array}$ & $\begin{array}{l}-0.1968 * * \\
(0.0848)\end{array}$ & $\begin{array}{l}-0.0539 * \\
(0.0344)\end{array}$ & $\begin{array}{l}-0.0914 * * \\
(0.0491)\end{array}$ \\
\hline $25 M S A$ & $\begin{array}{l}0.1043 \\
(0.1755)\end{array}$ & $\begin{array}{l}0.2260 \\
(0.2286)\end{array}$ & $\begin{array}{l}-0.0597 \\
(0.0878)\end{array}$ & $\begin{array}{l}-0.0439 * * * \\
(0.0129)\end{array}$ & $\begin{array}{l}-0.0588 * * \\
(0.0232)\end{array}$ \\
\hline LEASE & $\begin{array}{l}-0.9134 \\
(1.0853)\end{array}$ & $\begin{array}{l}3.1154 * * * \\
(1.0416)\end{array}$ & $\begin{array}{l}-0.1215 \\
(0.3300)\end{array}$ & $\begin{array}{l}-0.1007 \\
(0.0793)\end{array}$ & $\begin{array}{l}-0.0899 \\
(0.0719)\end{array}$ \\
\hline$A L T M A N$ & $\begin{array}{l}0.0004 \\
(0.0171)\end{array}$ & $\begin{array}{l}-0.0056 \\
(0.0286)\end{array}$ & $\begin{array}{l}0.0100 \\
(0.0435)\end{array}$ & $\begin{array}{l}0.0015 \\
(0.0435)\end{array}$ & $\begin{array}{l}0.0023 \\
(0.0060)\end{array}$ \\
\hline TYPE & Yes & Yes & Yes & Yes & Yes \\
\hline No. of obs & 393 & 422 & 422 & 422 & 422 \\
\hline $\mathrm{R} 2$ & 0.6820 & 0.6221 & 0.8522 & 0.8876 & 0.9372 \\
\hline
\end{tabular}

This table reports the results of the Fama-MacBeth regressions based on a panel of US Equity REITs across 2003 and 2015. The dependent variables are three different valuation measures including price-toFFO (P/FFO), market-to-Book value (M/B) and Tobin's $\mathrm{Q}(Q)$, as well as two determinants for the discount factor including the turnover which is the total value of the trading volume of a company for a given year divided by the end-of-year outstanding value of the common stocks (TURNOVER) and the dividend growth rate $(D I V G R O W T H)$. We use an alternative measure to proxy for the tenant concentration which is the total number of tenants for each REIT (Tenant_No.). The geographic and property type concentration is also measured by the Herfindahl index (HHI_Geo and HHI_Type respectively) based on the shares of assets across MSAs and property types respectively. We also control for the long-term lease (LEASE), which is the share of base rents to be received from operating leases expiring during the sixth and thereafter fiscal years following the current fiscal year, and the tenant quality measured by the Altman Z-score (ALTMAN). The other control variables are as follows: the size of the REIT company measured by its market capitalization $(S I Z E), \log$-transformed; the financial leverage defined as the total debt divided by the book value of equity $(D / E)$; the growth rate of the real estate investments $(G R O W T H)$; and the total share of properties located in MSA regions (25MSA). We also control for the fixed effect of REIT types (TYPE). Standard errors are in the parentheses. $* * *, * *, *$ denote significance level at $1 \%, 5 \%$ or $10 \%$ respectively

\subsection{Other robustness tests}

Finally, we also run a series of other robustness tests to further strengthen our findings and results are presented in Table 12. For parsimonious reasons, we only report the results on the variable of interest-HHI_Tenant while the same group of control variables are included in the specifications. Firstly, to eliminate the concern that our results are driven by a few REITs with a $100 \%$ tenant concentration, we exclude those REITs with HHI_Tenant 


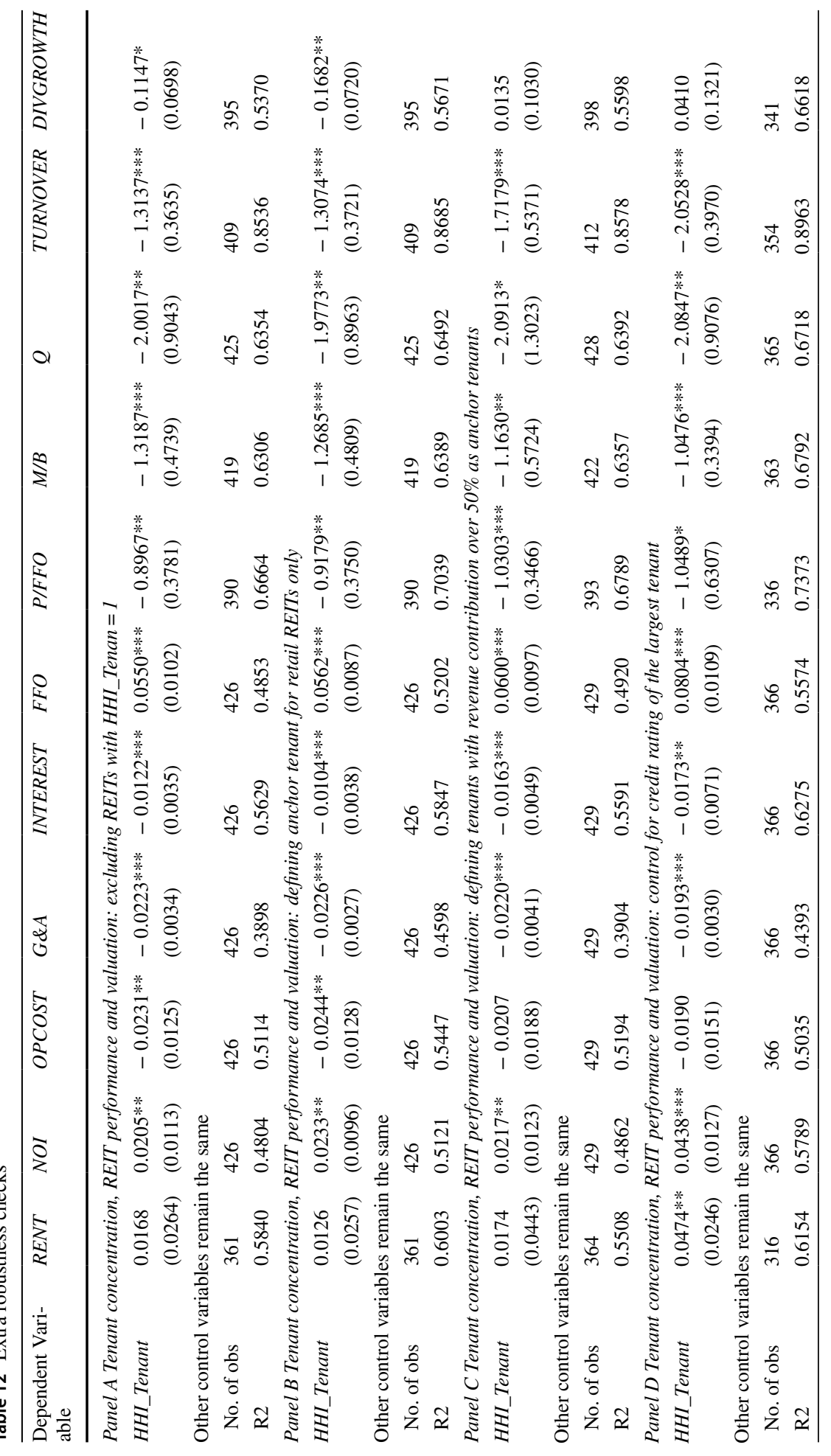




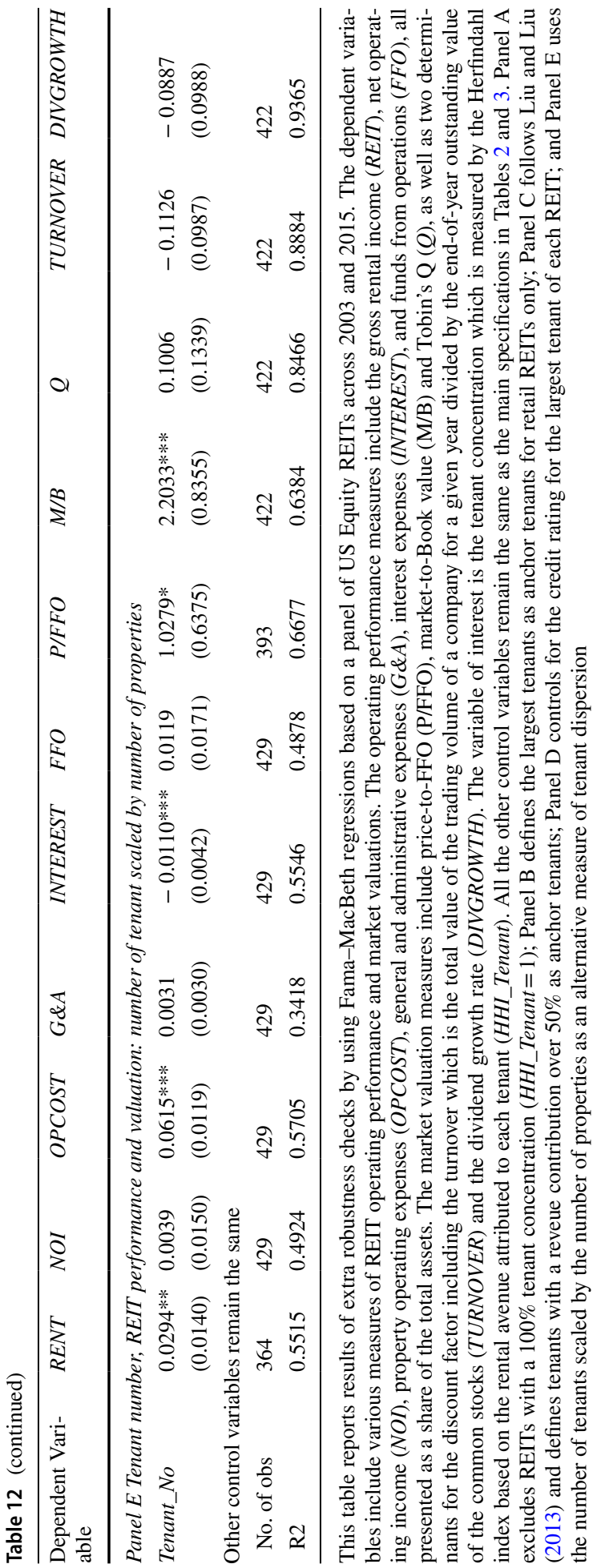


equal to 1 (Panel A). Secondly, we use two alternative measures of the anchor tenant effect: we identify the anchor tenants for retail REITs only as one might argue that this is a phenomenon exclusive to the retail sector (Panel B); we also follow Liu and Liu (2013) and identify only tenants with a revenue contribution over $50 \%$ as anchor tenants (Panel C). Thirdly, the impact of tenant concentration might be distorted by the extreme credit ratings of the dominant tenants. We account for this by adding a control variable for the credit rating of the largest tenant of each REIT (Panel D). Lastly, as REITs with more properties are more likely to have a more dispersed tenant pool, we scale the number of tenants by the number of properties owned by each REIT (Panel E). The results are presented in Panel E. We can see from Table 12 that our findings survive through all these extra robustness tests. Overall, the robustness tests strengthen our findings and show that tenant concentration matters significantly to the operating performance and valuations of REITs.

\section{Conclusion}

In this study, we examine the impact of tenant concentration on REITs operating performance and market valuations. We use the Herfindahl index to measure the level of tenant concentration for a given REIT company based on the revenue attribution by each tenant. While the impact of tenant concentration on property-level cash flows is inconclusive, we document a significantly positive relationship between tenant concentration and REIT corporate cash flows, driven by the reduced management and financial expenses associated with a concentrated tenant base. However, this improved cash flow does not translate into firm value as we identify a concentration discount effect that REITs with a more concentrated tenant base experience lower market valuations, which is in sharp contrast to previous studies supporting a diversification discount effect (Capozza and Seguin 1999; Cronqvist et al. 2001; Campbell et al. 2003; García and Norli 2012; Ro and Ziobrowski 2012). We argue that the concentration discount is fundamentally driven by the increased risk, hence discount factor, associated with a more concentrated tenant base, in line with the business research literature which believes that the corporate risk is increased when relying on concentrated customers (Kwak and Kim 2020; Lee et al. 2020). Our results hold after we control for various tenant characteristics, geographic and property type concentration and stand through a variety of robustness tests. Our findings imply that it is not just the lease structure and the tenant quality that matter to REITs, tenant concentration also directly impacts on REITs performance. This study also provides evidence that a supplier relying on a concentrated customer base can benefit from the improved operating efficiency as well as suffering from the increased risk. We believe that this study draws attention to the importance of the underlying tenants and sheds some light on future studies about REITs and customer concentration.

\section{Appendix}

See Table 13. 
Table 13 Correlation coefficient matrix

\begin{tabular}{|c|c|c|c|c|c|c|c|c|c|}
\hline & $\begin{array}{l}\text { HHI_Ten- } \\
\text { ant }\end{array}$ & HHI_Geo & HHI_Type & $R E N T$ & $N O I$ & OPCOST & $G \& A$ & INTEREST & $F F O$ \\
\hline HHI_Tenant & 1 & & & & & & & & \\
\hline HHI_Geo & -0.01 & 1 & & & & & & & \\
\hline HHI_Type & 0.17 & 0.02 & 1 & & & & & & \\
\hline RENT & 0.19 & 0.15 & -0.06 & 1 & & & & & \\
\hline NOI & -0.31 & 0.32 & -0.13 & 0.62 & 1 & & & & \\
\hline OPCOST & 0.32 & -0.24 & 0.01 & 0.63 & 0.12 & 1 & & & \\
\hline$G \& A$ & 0.05 & -0.08 & -0.09 & -0.06 & -0.10 & 0.12 & 1 & & \\
\hline INTEREST & -0.32 & 0.01 & -0.38 & 0.33 & 0.53 & 0.09 & -0.12 & 1 & \\
\hline$F F O$ & 0.41 & -0.21 & 0.17 & 0.51 & -0.04 & 0.90 & -0.14 & -0.23 & 1 \\
\hline$P / F F O$ & -0.05 & 0.08 & 0.13 & -0.25 & -0.24 & -0.02 & 0.15 & -0.38 & 0.07 \\
\hline$M / B$ & 0.04 & -0.16 & 0.20 & -0.01 & -0.13 & 0.40 & 0.10 & -0.26 & 0.45 \\
\hline$Q$ & -0.10 & -0.15 & -0.02 & 0.09 & 0.10 & 0.43 & 0.13 & 0.03 & 0.36 \\
\hline SIZE & -0.22 & 0.10 & 0.08 & -0.09 & 0.10 & -0.26 & -0.18 & -0.13 & -0.15 \\
\hline$D / E$ & -0.18 & 0.21 & -0.18 & 0.01 & 0.22 & 0.00 & -0.11 & 0.36 & -0.09 \\
\hline GROWTH & 0.04 & 0.01 & 0.04 & -0.31 & -0.32 & -0.03 & -0.02 & -0.37 & 0.11 \\
\hline $25 M S A$ & -0.15 & 0.04 & 0.11 & -0.33 & -0.04 & -0.32 & -0.21 & 0.02 & -0.26 \\
\hline TURNOVER & -0.13 & 0.23 & 0.10 & 0.02 & 0.15 & -0.22 & -0.13 & 0.09 & -0.21 \\
\hline DIVGROWTH & 0.04 & -0.05 & 0.14 & -0.04 & -0.08 & 0.04 & 0.03 & -0.03 & 0.04 \\
\hline LEASE & -0.21 & 0.02 & -0.15 & 0.00 & 0.24 & -0.06 & -0.12 & 0.30 & -0.13 \\
\hline \multirow[t]{2}{*}{ ALTMAN } & -0.22 & -0.11 & 0.05 & -0.16 & 0.06 & -0.13 & -0.16 & -0.05 & -0.06 \\
\hline & $\begin{array}{ll}P / F F O & M / B\end{array}$ & $Q$ & SIZE & $G R O$ & VTH & $\begin{array}{l}\text { TURN- } \\
\text { OVER }\end{array}$ & $\begin{array}{l}\text { DIV- } \\
\text { GROW }\end{array}$ & LEASE & $\begin{array}{l}A L T- \\
M A N\end{array}$ \\
\hline
\end{tabular}

\begin{tabular}{|c|c|c|c|c|c|c|c|c|c|c|c|}
\hline$P / F F O$ & 1 & & & & & & & & & & \\
\hline$M / B$ & 0.44 & 1 & & & & & & & & & \\
\hline$Q$ & 0.46 & 0.64 & 1 & & & & & & & & \\
\hline SIZE & 0.19 & 0.09 & 0.21 & 1 & & & & & & & \\
\hline$D / E$ & -0.13 & 0.04 & 0.27 & -0.07 & 1 & & & & & & \\
\hline GROWTH & 0.21 & 0.23 & 0.07 & -0.14 & 0.04 & 1 & & & & & \\
\hline $25 M S A$ & 0.07 & 0.04 & 0.01 & 0.05 & 0.20 & -0.02 & 1 & & & & \\
\hline TURNOVER & -0.14 & -0.22 & -0.15 & 0.45 & 0.05 & -0.20 & 0.02 & 1 & & & \\
\hline $\begin{array}{l}\text { DIV- } \\
\quad \text { GROWTH }\end{array}$ & 0.04 & 0.11 & 0.12 & 0.00 & -0.05 & 0.01 & -0.07 & -0.09 & 1 & & \\
\hline LEASE & 0.01 & -0.06 & 0.22 & 0.19 & 0.30 & -0.21 & 0.15 & 0.05 & -0.05 & 1 & \\
\hline ALTMAN & 0.16 & 0.13 & 0.21 & 0.19 & -0.01 & 0.04 & 0.26 & -0.08 & -0.01 & 0.19 & 1 \\
\hline
\end{tabular}

This table presents the correlation coefficients between variables. The operating performance measures include the gross rental income $(R E I T)$, net operating income (NOI), property-level aggregated operating expenses (OPCOST), general and administrative expenses $(G \& A)$, interest expenses (INTEREST), and funds from operations $(F F O)$, all presented as a share of the total assets. Market valuations include priceto-FFO $(P / F F O)$, market-to-book value $(M / B)$ and Tobins $\mathrm{Q}(Q)$. The tenant concentration is measured by the Herfindahl index based on the rental avenue attributed to each tenant (HHI_Tenant). The geographic and property-type concentration is also measured by the Herfindahl index (HHI_Geo and HHI_Type respectively) based on the shares of assets across MSAs and property types respectively. LEASE measures the long-term lease which is the share of base rents to be received from operating leases expiring during the sixth and thereafter fiscal years following the current fiscal year. ALTMAN is the Altman Z-score for the tenant quality. SIZE is the market capitalization of the REIT company, log-transformed in the regressions. $D / E$ is the financial leverage defined as the total debt divided by the book value of equity. GROWTH is the growth rate of the real estate investments. 25MSA is the total share of properties located in MSA regions. TURNOVER is the total value of the trading volume of a company for a given year divided by the end-ofyear outstanding value of the common stocks. DIVGROWTH IS the dividend growth rate 
Open Access This article is licensed under a Creative Commons Attribution 4.0 International License, which permits use, sharing, adaptation, distribution and reproduction in any medium or format, as long as you give appropriate credit to the original author(s) and the source, provide a link to the Creative Commons licence, and indicate if changes were made. The images or other third party material in this article are included in the article's Creative Commons licence, unless indicated otherwise in a credit line to the material. If material is not included in the article's Creative Commons licence and your intended use is not permitted by statutory regulation or exceeds the permitted use, you will need to obtain permission directly from the copyright holder. To view a copy of this licence, visit http://creativecommons.org/licenses/by/4.0/.

\section{References}

Acharya VV, Pedersen LH (2005) Asset pricing with liquidity risk. J Financ Econ 77:375-410

Ahn S, Denis DJ (2004) Internal capital markets and investment policy: evidence from corporate spinoffs. J Financ Econ 71:489-516

Alcock J, Steiner E (2018) Fundamental drivers of dependence in REIT returns. J Real Estate Finance Econ $57: 4-42$

Ambrose B, Shafer M, Yildirim Y (2018) The impact of tenant diversification on spreads and default rates for mortgages on retail properties. J Real Estate Finance Econ 56:1-32

Amihud Y, Mendeison H (1988) Liquidity and asset prices: financial management implications. Financ Manag 17:5-15

Ang A, Hodrick RJ, Xing Y, Zhang X (2006) The cross-section of volatility and expected returns. J Finance 61:259-299

Barinov A (2014) Turnover: liquidity or uncertainty? Manag Sci 60:2478-2495

Berger PG, Ofek E (1995) Diversification's effect on firm value. J Financ Econ 37:39-65

Best RW, Hodges CW, Lin B-X (2004) Does information asymmetry explain the diversification discount? J Financ Res 27:235-249

Bielstein P, Fischer M, Kaserer C (2018) The cost of capital effect of M\&A transactions: disentangling coinsurance from the diversification discount. Eur Financ Manag 24:650-679

Campbell RD, Petrova M, Sirmans CF (2003) Wealth effects of diversification and financial deal structuring: evidence from REIT property portfolio acquisitions. Real Estate Econ 31:347-366

Capozza DR, Seguin PJ (1999) Focus, transparency and value: the REIT evidence. Real Estate Econ 27:587-619

Chen SS, Chen I-J (2011) Inefficient investment and the diversification discount: evidence from corporate asset purchases. J Bus Finance Account 38:887-914

Cheng J-C, Wu R-S (2018) Internal capital market efficiency and the diversification discount: the role of financial statement comparability. J Bus Finance Account 45:572-603

Comment R, Jarrell G (1995) Corporate focus and stock returns. J Financ Econ 37:67-87

Cronqvist H, Högfeldt P, Nilsson M (2001) Why agency costs explain diversification discounts. Real Estate Econ 29:85-126

Dittmar A, Shivdasani A (2003) Divestitures and divisional investment policies. J Finance 58:2711-2744

Fama EF, Macbeth JD (1973) Risk, return, and equilibrium: empirical tests. J Political Econ 81:607-636

Feng Z, Pattanapanchai M, Price SM, Sirmans CF (2019) Geographic diversification in real estate investment trusts. Real Estate Econ 49:267-286

García D, Norli Ø (2012) Geographic dispersion and stock returns. J Financ Econ 106:547-565

Glascock JL, Lu-Andrews R (2015) The price behavior of REITs surrounding extreme market-related events. J Real Estate Finance Econ 51:441-479

Hadlock CJ, Ryngaert M, Thomas S (2001) Corporate structure and equity offerings: are there benefits to diversification? J Bus 74:613-635

Hartzell JC, Sun L, Titman S (2014) Institutional investors as monitors of corporate diversification decisions: evidence from real estate investment trusts. J Corp Finance 25:61-72

Hund J, Monk D, Tice S (2010) Uncertainty about average profitability and the diversification discount. J Financ Econ 96:463-484

Irvine PJ, Park SS, Yıldızhan C (2016) Customer-base concentration, profitability, and the relationship life cycle. Account Rev 91:883-906

Kang J-K, Kim J-M (2008) The geography of block acquisitions. J Finance 63:2817-2858

Krishnaswami S, Subramaniamb V (1999) Information asymmetry, valuation, and the corporate spin-off decision. J Financ Econ 53:73-112 
Kwak K, Kim N (2020) Concentrate or disperse? The relationship between major customer concentration and supplier profitability and the moderating role of insider ownership. J Bus Res 109:648-658

Lamont OA, Polk CK (2002) Does diversification destroy value? Evidence from the industry shocks. J Financ Econ 63:51-77

Landier A, Nair VB, Wulf J (2009) Trade-offs in staying close: corporate decision making and geographic dispersion. Rev Financ Stud 22:1119-1148

Lang LHP, Stulz RM (1994) Tobin's q, corporate diversification, and firm performance. J Political Econ 106:1248-1280

Lee SM, Jiraporn P, Song H (2020) Customer concentration and stock price crash risk. J Bus Res 110:327-346

Ling DC, Naranjo A, Scheick B (2018a) Geographic portfolio allocations, property selection and performance attribution in public and private real estate markets. Real Estate Econ 46:404-448

Ling DC, Naranjo A, Scheick B (2018b) There's no place like home: information asymmetries, local asset concentration, and portfolio returns. Real Estate Econ 49:36-74

Liu CH, Liu P (2013) Is what's bad for the goose (tenant), bad for the gander (landlord): a retail real estate perspective. J Real Estate Res 35:1-17

Liu CH, Liu P, Zhang Z (2019) Real assets, liquidation value and choice of financing. Real Estate Econ 47:478-508

Lu C, Mao T, Shen Y-P (2015) Beyond friendly acquisitions: the case of REITs. Rev Quant Financ Acc 44:139-159

Lu-Andrews R (2017) Tenant quality and REIT liquidity management. J Real Estate Finance Econ 2017:272-296

Montgomery CA (1994) Corporate diversification. J Econ Perspect 8:163-178

Newey WK, West KD (1987) A simple, positive semi-definite, heteroskedasticity and autocorrelation consistent covariance matrix. Econometrica 55:703-708

Patatoukas PN (2012) Customer-base concentration: implications for firm performance and capital markets. Account Rev 87:363-392

Rajan R, Servaes H, Zingales L (2000) The cost of diversity: the diversification discount and inefficient investment. J Finance 55:35-80

Ro S, Ziobrowski AJ (2012) Wealth effects of REIT property-type focus changes: evidence from property transactions and joint ventures. J Prop Res 29:1-23

Rosenthal SS, Strange WC (2020) How close is close? The spatial reach of agglomeration economies. J Econ Perspect 34:27-49

Scharfstein DS, Stein JC (2000) The dark side of internal capital markets: divisional rent—seeking and inefficient investment. J Finance 55:2537-2564

Shin H-H, Stulz RM (1998) Are internal capital markets efficient? Q J Econ 113:531-552

Thomas S (2002) Firm diversification and asymmetric information: evidence from analysts' forecasts and earnings announcements. J Financ Econ 64:373-396

Wheaton WC (2000) Percentage rent in retail leasing: the alignment of landlord-tenant interests. Real Estate Econ 28:185-204

Publisher's Note Springer Nature remains neutral with regard to jurisdictional claims in published maps and institutional affiliations. 